\title{
Nanocomposite Multilayer Binary Nitride Coatings Based on Transition and Refractory Metals: Structure and Properties
}

\author{
Alexander Pogrebnjak ${ }^{1,2, *}$, Kateryna Smyrnova ${ }^{1}\left[\right.$ and Oleksandr Bondar ${ }^{1}$ (D) \\ 1 Department of Nanoelectronics, Sumy State University, Rymskogo-Korsakova st. 2, 40007 Sumy, Ukraine; \\ kateryna.v.smyrnova@gmail.com (K.S.); oleksandr.v.bondar@gmail.com (O.B.) \\ 2 Center of Advanced Development "Veritas", D. Serikbayev East Kazakhstan State Technical University, \\ Protozanov st. 69, 070004 Ust-Kamenogorsk, Republic of Kazakhstan \\ * Correspondence: alexp@i.ua; Tel.: +380-662376564
}

Received: 14 January 2019; Accepted: 26 February 2019; Published: 27 February 2019

\begin{abstract}
One area of constant interest in many fields of industry is development of functional multilayer coatings that possess excellent performance characteristics. That is why in our brief review the results of studies of structure and properties of multilayer structures based on binary nitrides of transition or refractory metals obtained by various physical-vapor deposition (PVD) techniques are presented. The influence of substrate temperature, substrate bias voltage, bilayer thickness and interface boundaries on the structure of coatings and their properties, such as hardness, plasticity, wear and corrosion resistance, are discussed in detail. This review may be useful for students and growing community of researchers interested in the synthesis-structure-properties relationship in multilayer coatings based on metal nitrides.
\end{abstract}

Keywords: multilayer coatings; physical-mechanical properties; structural-phase state; wear; friction; microstructure

\section{Introduction}

Over the last few decades, an intensive development of the modern technologies has stimulated the need to improve protective properties of materials that are used in the manufacture of cutting tools, turbine blades, reactor walls, biomedical implants and so forth. Enhanced hardness, service life, resistance to wear and oxidation under high temperatures are among the list of the most essential properties that such materials must possess. From this point of view, the most profitable way to satisfy all the requirements is the creation of a thin coating with the desired characteristics on the surface of a product material that protects the latter from the destruction when operating under extreme conditions. Particularly, multilayer structures are very popular for this application.

The multilayer nitride coatings have been being actively investigated since the last quarter of the 20th century due to the numerous possible applications in the modern aerospace industry, manufacturing, medicine and so forth [1-8]. From the very moment of the first mention of these structures to the present, researchers have collected a lot of information about the deposition techniques, structure, properties and further perspectives of application. It was found that binary metal nitrides exhibit improved characteristics compared to conventional metals [9-13]. Furthermore, multilayer nitride coatings demonstrate excellent durability, wear and corrosion resistance, mechanical, optical, electronic and magnetic properties [14-19]. The specific characteristics of nitride materials directly depend on their structure and types of chemical bonds formed between their constituent elements [20]. 
Overall, nitrides are simple metal structures with smaller in size nitrogen atoms that are placed in the interstitial sites (octahedral holes) of a close-packed lattice. Metal nitrides typically have face-centred cubic (fcc) or hexagonal close-packed (hcp) metal lattices with non-metal atoms, which more or less randomly distributed in the interstitial gaps. However, this concept is not often strict and there can be some deviations in practice. Three combinations of chemical bonds between atoms are possible depending on the metal that reacts with nitrogen (Figure 1) [21,22]. First, the metallic bond that is characterized by a finite density of states at the Fermi level $\left(E_{\mathrm{F}}\right)$ [23]. Second, the covalent bond, which occurs between the d-state metal atom and nitrogen in the p-state with a certain interaction of "metal-metal" [24-26]. Third, the ionic bond that is formed as a result of the transfer of electrons from the metal atoms to the nitrogen; as a rule these elements must have a high difference in the electronegativity $[27,28]$.

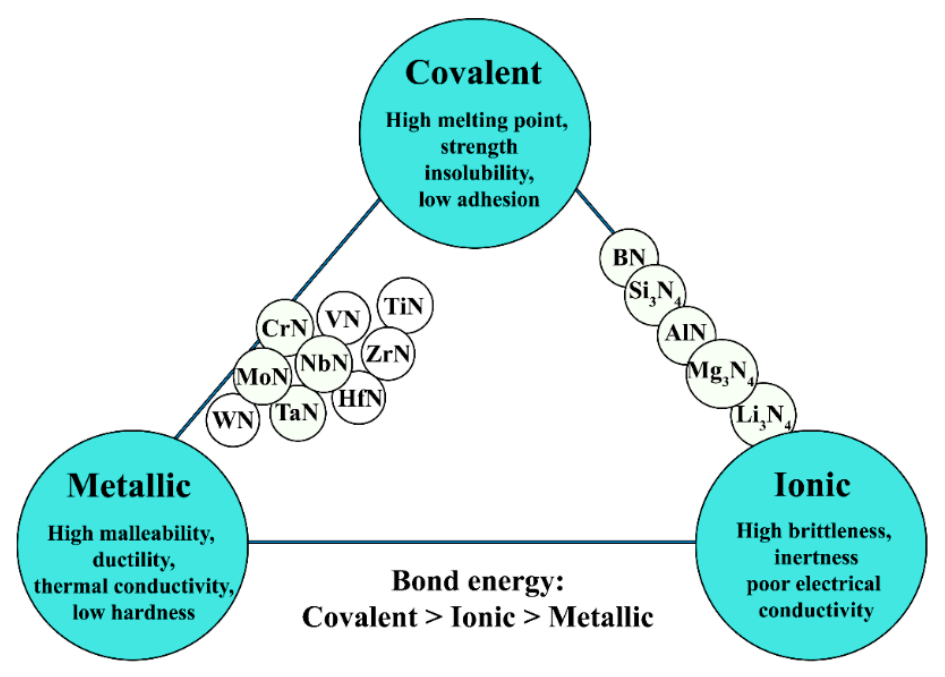

Figure 1. Chemical bonds and properties of some nitrides. Adapted from [29].

The last, ionic, group of the chemical bonds includes nitrides of the alkali $\left(\mathrm{Li}_{3} \mathrm{~N}\right)$ and the alkaline earth metals $\left(\mathrm{Mg}_{3} \mathrm{~N}_{2}, \mathrm{Ca}_{3} \mathrm{~N}_{2}, \mathrm{Ba}_{3} \mathrm{~N}_{2}\right.$, etc.), whose atoms have electrons in outer orbits [30]. Covalent nitrides can be formed by the bonding of nitrogen with the metal and non-metal atoms that have electrons in p-orbital (B, Al, Si, Ga, Ge, etc.). Nitrides of transition metals, which are characterized by partly filled d- or f-shells, consist of nitrogen (solute atom) that is placed in the crystalline lattice of the host transition metal [9]. They have quite complex composition, which does not correspond to the common oxidation states ( $\mathrm{TiN}, \mathrm{ZrN}, \mathrm{Cr}_{2} \mathrm{~N}, \mathrm{Mn}_{3} \mathrm{~N}_{2}$ ), moreover, transition metals form in some cases several forms of nitrides, for example $\mathrm{Nb}_{2} \mathrm{~N}$ and $\mathrm{NbN}, \mathrm{Ta}_{2} \mathrm{~N}, \mathrm{Ta}_{3} \mathrm{~N}_{5}$ and $\mathrm{TaN}$ and so forth. Generally, transition metal nitrides have a combination of different types of chemical bonds [31]. The proportions of each bond depend on the filling of $\mathrm{d}$ - or $\mathrm{f}$-shells in the metal and its ionization energy [32-34]. Due to the participation of not only external s-electrons in the bond formation between metal and nitrogen atoms but also significantly deeper d-electrons, the chemical bonds in such nitrides are very strong. When we consider transition metals of the IV-VI groups in the direction $\mathrm{Ti} \rightarrow \mathrm{Cr}$, $\mathrm{Zr} \rightarrow \mathrm{Mo}, \mathrm{Hf} \rightarrow \mathrm{W}$ statistical weight of the $\mathrm{sp}^{3}$ and $\mathrm{d}^{5}$ configurations gradually decreases and increases, respectively. This means that in MeN compounds the Me-Me interactions become stronger, whilst the covalent and ionic bonds weaken. That is a reason why some transition metal nitrides have lower melting temperature $\left(T_{\mathrm{M}}\right)$ than a host metal, for instance $\mathrm{CrN}$ and $\mathrm{MoN}$ (Table 1). It can be explained by the fact that the strength of the weakest bonds, along which vibrations of the lattice are excited, determines $T_{\mathrm{M}}$. Nitrides of chromium and molybdenum have mainly metallic component that easily breaks under elevated temperatures [35,36]. 
Table 1. Comparison of the melting temperatures $\left(T_{M}\right)$ of some transition metals and their nitrides.

\begin{tabular}{cc}
\hline Metal/Nitride & $\boldsymbol{T}_{\mathbf{M}}\left({ }^{\circ} \mathbf{C}\right)$ \\
\hline $\mathrm{Ti} / \mathrm{TiN}$ & $1668 / 3290$ \\
$\mathrm{Zr} / \mathrm{ZrN}$ & $1855 / 2960$ \\
$\mathrm{Hf} / \mathrm{HfN}$ & $2233 / 3305$ \\
$\mathrm{~V} / \mathrm{VN}$ & $1910 / 2050$ \\
$\mathrm{Ta} / \mathrm{TaN}$ & $3015 / 3090$ \\
$\mathrm{Cr} / \mathrm{CrN}$ & $1907 / 1770$ \\
$\mathrm{Mo} / \mathrm{MoN}$ & $2010 / 1750$ \\
\hline
\end{tabular}

Furthermore, many transition metal-based nitrides are good superconductors that have high hardness and high heat resistance. For instance, the superconducting transition temperature for niobium nitride and molybdenum nitride are -258 and $-261{ }^{\circ} \mathrm{C}$, respectively. These materials are characterized by a high melting point, hardness, corrosion resistance, good electrical and thermal conductivity [14,37-40]. Due to the universal and simultaneously some unique properties, nitride coatings from transition metals are widely applied as structural materials in engineering, nuclear and chemical industries, in the production of abrasives, cutting tools, wear-resistant materials and so forth [41-45]. It is worth noting that some of the transition metal nitrides show superconducting properties at atmospheric pressure. Relatively high critical temperature and stability make such coatings the potential candidates for using in the superconducting devices, such as single-photon detectors or hot-electron bolometric mixers [46-52]. Hence, because of the listed advantages multilayer coatings often are designed based on transition and refractory metal nitrides. Their combination as alternating layers in one multilayer material endow the latter with outstanding mechanical, tribological, electrical, optical and magnetic properties.

Herein, the present paper will discuss general features of nanostructured multilayer systems, their microstructure and functional characteristics, such as corrosion resistance, physical-mechanical and tribological properties. In order to highlight characteristics of nitrides, based on transition and refractory metals obtained by PVD techniques, we consider some examples of modern multilayer nanoscale protective coatings.

\section{General Features of Multilayer Coatings}

An abiding scientific interest in the multilayer coatings can be explained by the fact that such structures as a whole can demonstrate excellent physical-mechanical characteristics that are unusual for their individual constituents. This is confirmed by various studies, for instance, according to works [53-56] electrical, optical, mechanical and tribological properties, as well as high-temperature oxidation resistance in multilayer systems are significantly higher compared to those in single-layer coatings. Furthermore, coatings with multilayer architecture can demonstrate a significant reduction of the specific wear rate in a wide range of different operating conditions, while maintaining high values of hardness and strength. For instance, $\mathrm{ZrN} / \mathrm{WN}$ coatings with bilayer thickness of about $30 \mathrm{~nm}$ demonstrated improved fracture resistance, enhanced hardness and Young's modulus compared to the single-layer $\mathrm{ZrN}$ and $\mathrm{WN}$ coatings; total thickness for all samples was $0.8 \mu \mathrm{m}$. Addition of $\mathrm{ZrN}$ (fcc) layers into $\mathrm{W}_{2} \mathrm{~N}$ (bcc) layers resulted in the relaxation of the compressive stress, the suppression of grain grows and the formation of a mixed polycrystalline structure ((111), (200) and (311) texture) in the $\mathrm{WN}$ layers. A low-energy interface between $\mathrm{ZrN}$ and $\mathrm{W}_{2} \mathrm{~N}$ planes provided a barrier to the promotion of dislocations across layers [57]. Multilayer structures also can demonstrate unique properties that are not inherent in their single-layer constituents. The $\mathrm{NbN} /$ AlN multilayers are a good example of the high-temperature superconductors, although $\mathrm{NbN}$ refers to the low-temperature superconductors and AlN belongs to the insulators [58].

In general, multilayer coatings are capable of combining a range of different functional characteristics related to: (i) the need to provide a certain magnitude and sign of final stresses; 
(ii) the inhibition of heat flows caused by the frictional heat sources during cutting; (iii) the formation of barriers for interdiffusion processes between the coating and the substrate.

The multilayer structure is obtained by alternating the deposition of layers $\mathrm{A}$ and $\mathrm{B}$, consisting of various elements, on the substrate (Figure 2). The thickness of two successive layers (bilayer) is called a modulation period $(\Lambda)$ of the multilayer coating. Such a structure makes it possible to simultaneously combine in one geometric body not only simple metal compounds with non-metals but also metastable and multicomponent materials. High density of defects in the metastable structures induces high compressive residual stresses that can cause a good performance under the working conditions. Treatment of the coatings with the ion implantation, high temperature and pressure transforms their structure and hence properties $[59,60]$. Moreover, changing the key parameters of multilayer coatings, such as the thickness of individual layers and the modulation period, significantly affects properties of the coatings. For instance, the possibility of achieving high-temperature superconductivity using multilayer coatings based on niobium nitride (low-temperature superconductor) and aluminium nitride (insulator), which are analogous to a material with a high critical temperature, is described in Ref. [58]. In addition, an important feature of multilayer coatings is the presence of a significant area of interphase boundaries that can cause an improvement of mechanical and tribological properties, whereas they are not characteristic of the single-layer coatings deposited from the same components. This is of great importance for metallic multilayer coatings that are widely used in X-ray optics [61].

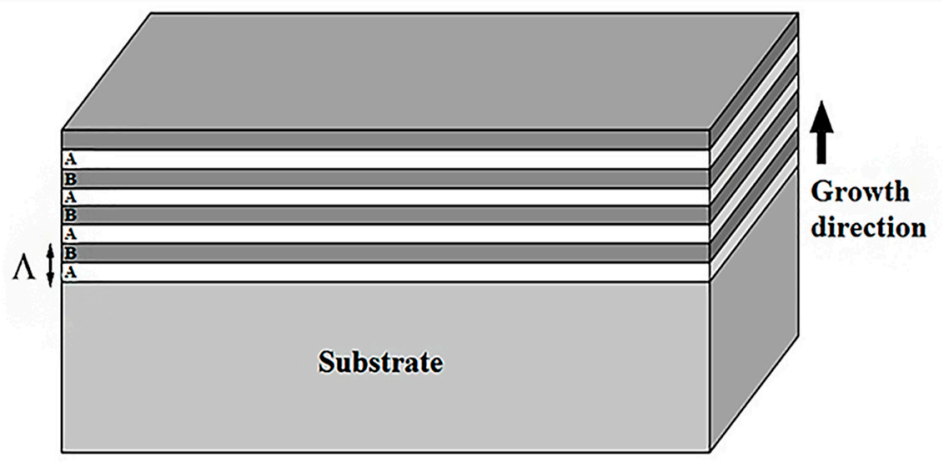

Figure 2. Schematic architecture of a multilayer coating.

Using multilayer coatings significantly alters the mechanism of wear due to the formation of the transition zones between the adjacent layers, which can hinder crack propagation or even relax them. A distinctive feature of multilayer structures is that the cracking in them occurs in the direction from the coating surface to the substrate, while single-layer ones exhibit cracking in two directions, from the surface and the substrate [62]. There have been reported a number of mechanisms contributing to the enhancement of mechanical properties of the multilayer coatings. They are coherency strains, effect of elastic anomalies, differences in the elastic modulus of each individual layer, Hall-Petch strengthening and so forth $[20,53]$. Enhanced oxidation, corrosion and wear resistance of the multilayer coatings arise due to the large number of interfaces and reduced grain sizes resulted in denser pore-free non-columnar microstructure [63].

The properties of multilayer coatings can be tuned not only by varying the bilayer thickness $\Lambda$ but also by changing the atomic spacing within the layers. Figure 3 a shows coherent interface between two layers occurred when interfacial plane has the same atomic configuration in both phases. In case of more significant mismatch of two lattices (one of the lattice parameters is grater) coherency strains take place in order to preserve the coherency of the interphase. This process leads to the accumulation of elastic energy in the coating. When a mismatch is too large such energetically unfavourable coherent interphase turns into more stable structure with defects (Figure $3 b$ ). Therefore, in multilayer coatings defects at interface boundaries and coherency strain can act as barriers for dislocation movement $[64,65]$. 


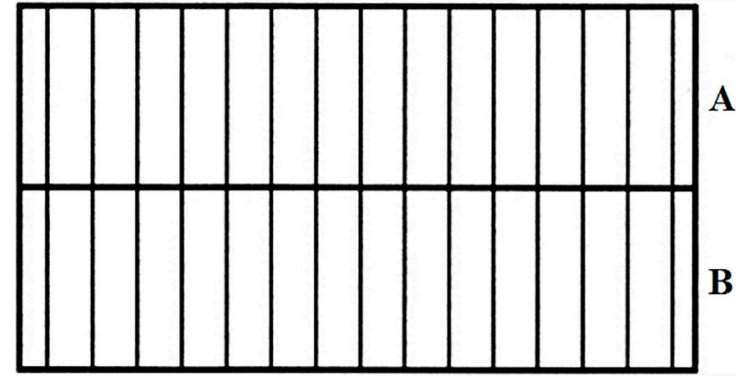

(a)

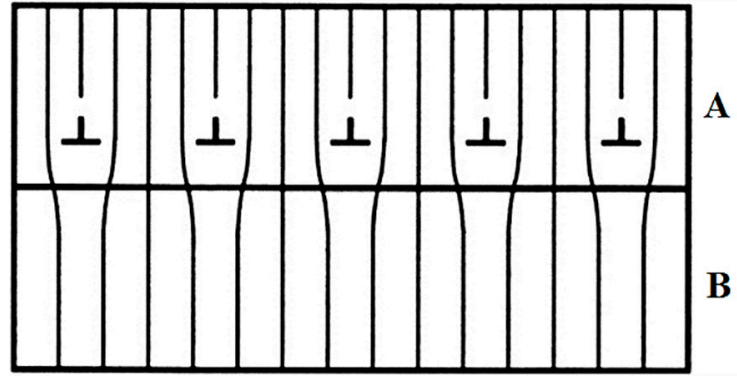

(b)

Figure 3. The interface between layers A and B (lattice parameter of the layer B is greater compared to that of the layer A): (a) coherent interface, where interplanar distances of the crystal lattices of both layers are equalized perpendicular to the interface; (b) incoherent interface, where misfit dislocations (indicated by $\perp$ ) compressive stresses at the relaxation of layers are formed [64].

Usually, in multilayer coatings, the interface between layers has a sufficiently strong bond that, in turn, prevents the formation and propagation of dislocations and nanocracks. Figure 4 shows the typical strengthening mechanisms in multilayer coatings [66,67]. Using materials with different mechanical properties can enhance these effects. The dislocations induced by the impact of the mechanical loads on the coating cannot be propagated through separate layers, since they need to overcome a high stresses existing in the multilayer coating [68]. Thus, the generated dislocations and nanocracks are weakened at the interfaces between individual layers.

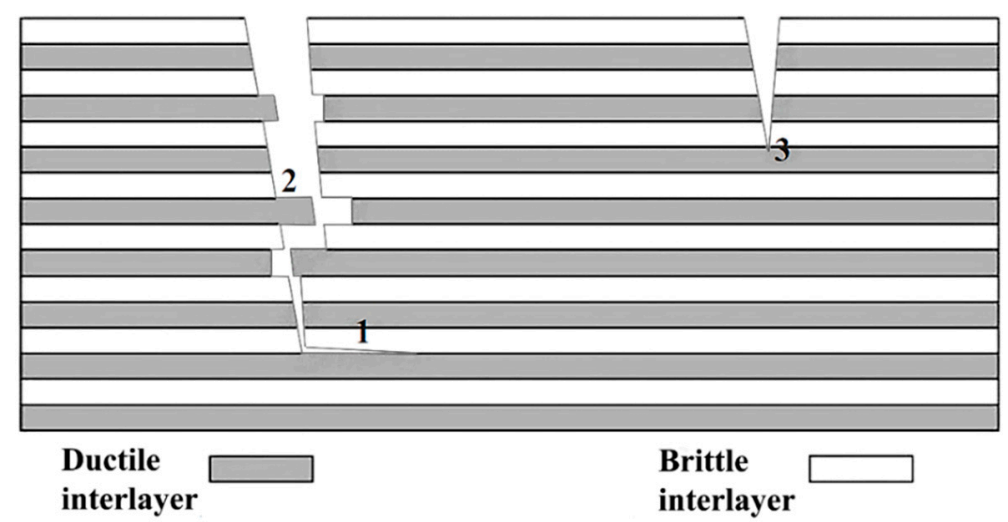

Figure 4. Toughening mechanisms: (1) crack deflection at the interfaces between layers; (2) coalescence of cracks at the interfaces; (3) crack tip blunting. Reprinted with permission from [69] 2005 Elsevier.

Many multilayer systems with tuned size of grains and their quantity, thickness and composition of each layer, thickness ratio of layers, the structure of interfaces have been developed for practical applications [70-72]. It should be noted that the right choice of the constituent elements of the layers is an essential step towards the creation of multilayer coatings with high functional properties [45,73-77]. As transition metal nitrides can combine even three main types of bonding, they may possess high hardness and strength (covalent component), thermal, electrical conductivity and ductility (metallic component), as well as chemical stability and inertness (ionic component).

Current advances in the deposition technologies indicate that multilayer coatings with different composition and excellent physical-mechanical and tribological properties can be produced using PVD and CVD methods [78-82]. Thus, there are many possibilities for modifying the characteristics of multilayer compositions but the synthesis of the coating structure should be carried out with high accuracy $[83,84]$. 


\section{Microstructure, Physical-Mechanical and Tribological Properties of Multilayer Coatings}

Intensive studies of multilayer coatings began with the Ref. [85]. This work for the first time described the concept of obtaining a multilayer coating with a micrometre thickness of layers. The coatings consisted of two layers, TiN $(5 \mu \mathrm{m})$ and TiC $(6 \mu \mathrm{m})$, were deposited onto cutting tool from constructional steel. Results of the study showed that such material significantly prolonged the lifetime of the tool compared to a single-layer $11 \mu \mathrm{m}$ thick TiN coating. The further development was characterized by the combinations of nitride, carbide, carbonitride and oxide materials, for example $\mathrm{TiN}, \mathrm{TiC}$, and/or TiCN with $\mathrm{Al}_{2} \mathrm{O}_{3}$ [86]. A layer of nitride or carbide provided a high strength and changes in the grain sizes in the oxide layer, while the oxide layer enhanced the chemical resistance, which makes this class of coatings promising candidates for cutting applications. The thickness of each individual layers was usually about $500 \mathrm{~nm}$ and the total thickness of the coatings varied within range of $5-10 \mu \mathrm{m}$.

Summarizing the first results of studies of multilayer coatings, the researchers concluded that the careful choice of composition, the strong chemical bonding and nano- and micrometres thickness of individual layers are the key factors affecting the properties of multilayer coatings. Varying these parameters allowed designing the first multilayer coatings with unique physical-mechanical properties. They had superb hardness ( $\geq 40 \mathrm{GPa}$ ), high thermal and chemical stability, good corrosion and wear resistance even under dry contact conditions [79,87-89].

Table 2 shows physical-mechanical properties of the multilayer binary nitride coatings studied by different authors using various methods of deposition. High-power impulse magnetron sputtering, unbalanced magnetron sputtering and vacuum-arc deposition are among the most promising main methods for obtaining multilayer coatings due to the relative simplicity of implementation process, the high repeatability of the results and the possibility of an industry-level implementation of these technologies. However, it should be noted that utilizing magnetron sputtering method results in the formation of the homogeneous layers, smooth surface but low adhesion strength and vacuum-arc deposition, on the contrary, provides a good adhesion between layers and substrate but at the same time leads to increase in the surface roughness. High roughness large amount of defects, pores and microdroplets, as well as a low adhesion strength in coatings decrease the performance characteristics as they are responsible for intensive cracking $[90,91]$. Thus, it is required to tune the deposition parameters in order to produce smother surface and maximum identity of each bilayer in the multilayer structures.

The TiN/VN multilayer coatings are one of the most successful examples of the superhard materials. Such combination of two different coatings results in the compensation of their shortcomings and the emergence of unique properties. Hardness of these multilayer coatings reached $56 \mathrm{GPa}$ when the thickness of bilayers was about $5.2 \mathrm{~nm}$ [102-104]. This value is close to that of the cubic BN and inferior to only the diamond. However, despite the fact that TiN/VN multilayer coatings demonstrated high hardness, their practical application was significantly limited by the enhanced susceptibility to oxidation, especially at high temperatures that vastly reduced their functional characteristics [105-107]. This problem was solved by designing the coatings based on $\mathrm{CrN}$ and AlN with improved thermal stability and high oxidation resistance, which were achieved without significant deterioration in hardness [108-111]. 
Table 2. Deposition parameters Mechanical properties of different bilayer nitride coatings.

\begin{tabular}{|c|c|c|c|c|c|c|c|}
\hline Coating & Deposition Technique & $\begin{array}{l}\text { Substrate Bias } \\
\text { Voltage (V) }\end{array}$ & $\begin{array}{c}\text { Total } \\
\text { Thicknes } \\
(\mu \mathrm{m})\end{array}$ & $\begin{array}{l}\text { Bilayer } \\
\text { Thickness } \\
\text { (nm) }\end{array}$ & $\begin{array}{l}\text { Hardness } \\
\text { (GPa) }\end{array}$ & $\begin{array}{l}\text { Young's } \\
\text { Modulus } \\
\text { (GPa) }\end{array}$ & Ref. \\
\hline $\mathrm{ZrN} / \mathrm{WN}$ & Magnetron sputtering & -40 & 0.8 & 30.4 & 34 & 423.8 & [57] \\
\hline $\mathrm{CrN} / \mathrm{ZrN}$ & $\begin{array}{l}\text { Unbalanced reactive } \\
\text { magnetron sputtering }\end{array}$ & -200 & $1.0 \div 1.2$ & 1.5 & 32 & 307.8 & [92] \\
\hline $\mathrm{CrN} / \mathrm{TiN}$ & $\begin{array}{l}\text { High-power impulse } \\
\text { magnetron sputtering }\end{array}$ & $\begin{array}{l}-1000 \mathrm{~V}+\text { constant } \\
\text { sputtering potential } \\
\text { of }-180 \mathrm{~V} \text { applied to } \\
\text { the } \mathrm{Cr} \text { facing Ti target }\end{array}$ & 2.0 & 6.4 & 26 & 375 & [93] \\
\hline $\mathrm{TiN} / \mathrm{NbN}$ & $\begin{array}{c}\text { DC planar } \\
\text { magnetron sputtering }\end{array}$ & -200 & 2.0 & 4.8 & 39.2 & - & [94] \\
\hline $\mathrm{TiN} / \mathrm{VN}$ & $\begin{array}{l}\text { Magnetron sputtering } \\
\text { Ion plating of TiN and }\end{array}$ & -420 & 2.5 & 4.8 & $44 \pm 10$ & - & [95] \\
\hline TiN/MoN & $\begin{array}{l}\text { magnetron sputtering } \\
\text { of MoN }\end{array}$ & -110 & $3.5 \pm 0.1$ & 9.0 & $29.0 \pm 2.5$ & - & [96] \\
\hline $\mathrm{TiN} / \mathrm{TaN}$ & $\begin{array}{l}\text { Ion plating of TiN and } \\
\text { magnetron sputtering of TaN }\end{array}$ & -110 & $3.5 \pm 0.1$ & 11 & $34.9 \pm 2.4$ & - & [96] \\
\hline $\begin{array}{c}\mathrm{CrN} / \mathrm{NbN} \\
(\mathrm{N} / \mathrm{Me}= \\
1)\end{array}$ & $\begin{array}{l}\text { Combined arc/unbalanced } \\
\text { magnetron sputtering }\end{array}$ & -75 & $3.0 \div 5.0$ & 3.54 & 42 & - & [97] \\
\hline $\mathrm{CrN} / \mathrm{TiN}$ & $\begin{array}{c}\text { Arc-free deep oscillation } \\
\text { magnetron } \\
\text { sputtering + pulsed DC } \\
\text { magnetron sputtering }\end{array}$ & -500 & $2.0 \div 3.0$ & 6.3 & 36 & $360 \pm 4$ & [98] \\
\hline $\mathrm{TiN} / \mathrm{ZrN}$ & Vacuum-arc evaporation & -200 & 19.0 & 39 & 42 & 347.39 & [99] \\
\hline $\mathrm{CrN} / \mathrm{MoN}$ & Vacuum-arc evaporation & -20 & 15.6 & 44 & 42.3 & - & [100] \\
\hline TiN/MoN & Vacuum-arc evaporation & -40 & $6.8 \div 8.2$ & 50 & 30 & 420 & [101] \\
\hline
\end{tabular}

The structural features of $\mathrm{ZrN} / \mathrm{TiN}$ multilayer structures and tribological characteristics of these coatings deposited by the magnetron stuttering method were studied by authors of the paper [112]. The scanning electron microscopy (SEM) image of their cross section shows that coatings had the column structure (Figure 5a). A dense fine-grained structure of $\mathrm{ZrN}$ and TiN layers is visible in the high-resolution transmission electron microscopy (HRTEM) image (Figure 5b). Although the initial roughness at the interface between the first layer and the substrate was very small, it accumulated as the number of deposited layers increased. According to the results of the research by atomic force microscopy, a rise in the bilayer thickness also enhance the surface roughness of the multilayer coating, which, in general, is quite typical for the magnetron sputtering. Tribological tests for milling tool with the $\mathrm{ZrN} / \mathrm{TiN}$ coatings demonstrated $30 \%$ prolongation of the tool life in extreme conditions compared with uncoated or coated with single-layer $\mathrm{ZnN}$ coatings. The modulation period of the multilayer structure was $6 \mathrm{~nm}$ and the total thickness of $\mathrm{ZrN} / \mathrm{TiN}$ and $\mathrm{ZrN}$ coatings including $\mathrm{Zr}$ buffer layer $(500 \mathrm{~nm})$ was $1.5 \mu \mathrm{m}$.

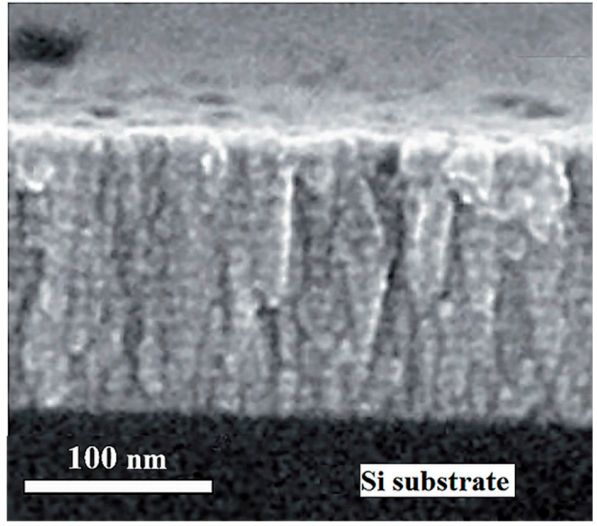

(a)

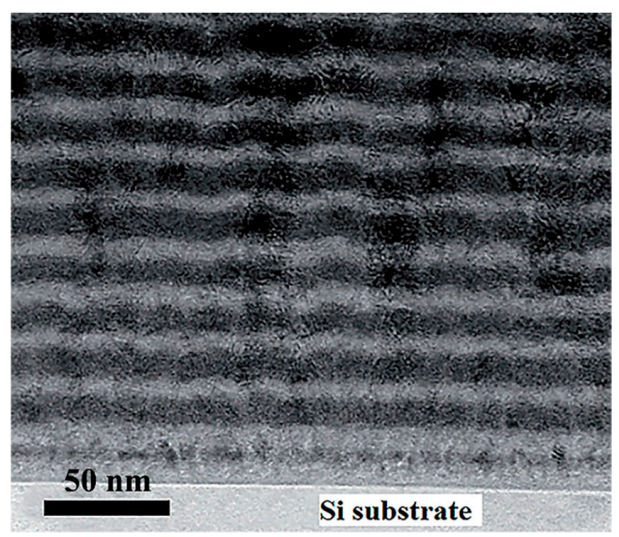

(b)

Figure 5. Cross sectional view of the TiN/ZrN multilayer coatings with bilayer thickness of $10 \mathrm{~nm}$ : deposited via magnetron sputtering of the silicon substrates (a) Scanning electron microscope (SEM) image; (b) High resolution transmission electron microscope (HRTEM) image [112]. 
The main factors contributing to the increase in the hardness of the multilayer coating are (i) the blocking of dislocations at the interfaces between layers [68,113], (ii) the Hall-Petch effect [114,115], (iii) the thermoelastic deformations at the boundaries between layer [116], (iiii) the supermodulus effect [117].

In the paper [96], the multilayer $\mathrm{TiN} / \mathrm{CrN}$, $\mathrm{TiN} / \mathrm{MoN}, \mathrm{TiN} / \mathrm{NbN}$ and $\mathrm{TiN} / \mathrm{TaN}$ coatings were deposited on the carbide substrates using a combination of two PVD methods. The ion beam sputtering technology was used to obtain the layers of titanium nitride and the magnetron sputtering method was employed for other layers. The deposited multilayer coatings had the NaCl-type cubic structure. The peak shift phenomenon was not observed in the X-ray diffraction (XRD) patterns (Figure 6). Furthermore, all multilayer coatings, except TiN/MoN, had a pronounced preferential (200) orientation. The TiN MoN was characterized by (111), (200) and (220) orientations. The preferential orientation for the single-layer TiN coating was (111). The investigation of residual stresses, hardness, adhesion and wear resistance of the $\mathrm{TiN} / \mathrm{MeN}(\mathrm{Me}=\mathrm{Cr}, \mathrm{Mo}, \mathrm{Nb}, \mathrm{Ta})$ multilayer coatings revealed that their mechanical and tribological characteristics are superior to the classical protective single-layer TiN coatings. The highest hardness values were recorded for $\mathrm{TiN} / \mathrm{CrN}$ structures, while TiN/TaN coatings had the highest abrasive wear resistance.

Multilayer coatings consisting of the alternating layers of transition and refractory metal nitrides can significantly improve the physical-mechanical and tribological properties of the protective coatings due to the combination of their best characteristics. However, existing multilayer materials are characterized by a high level of the internal compressive stresses, which causes tensile stresses in the substrate that, in turn, lead to a decrease in strength characteristics. Hence, further investigation of multilayer coatings based on alternating layers of transition metal nitrides is required.

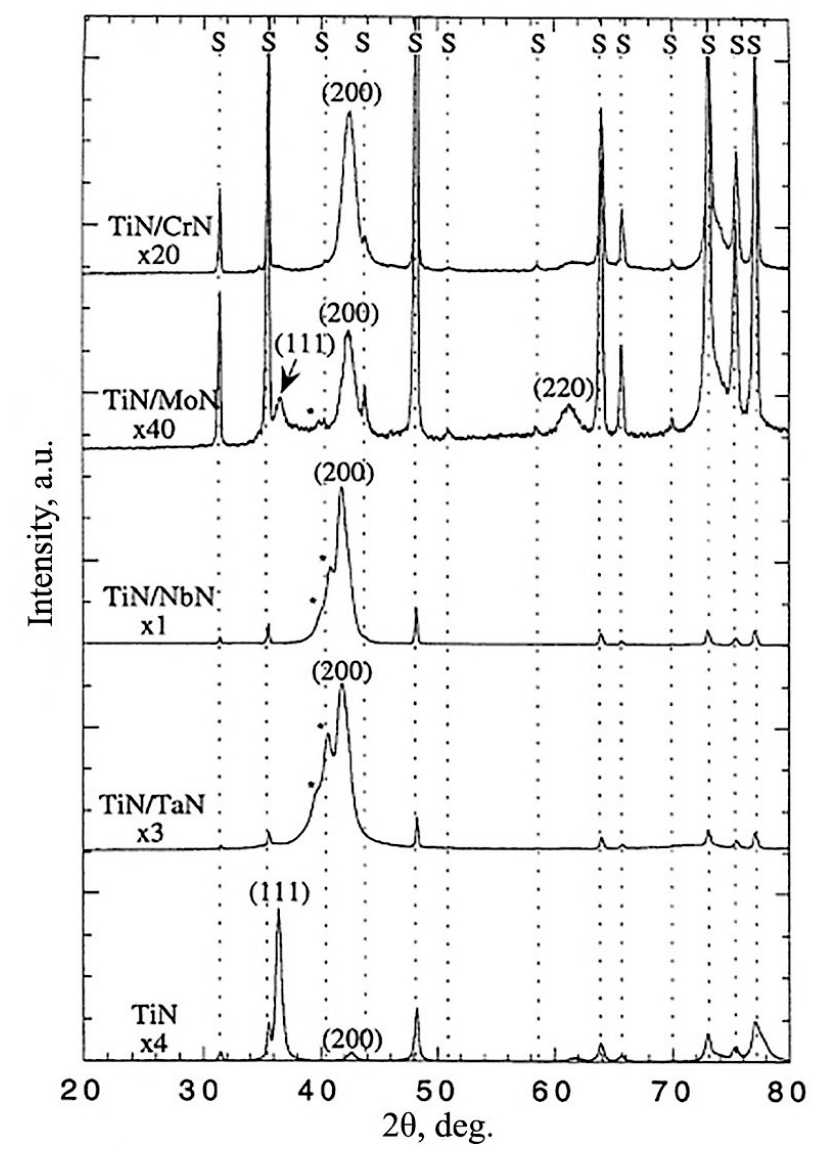

Figure 6. X-ray diffraction patterns of TiN/CrN, TiN/MoN, TiN/NbN and TiN/TaN coatings; "S" and "**" indicate peaks from the carbide substrate and the superlattice, respectively. Reprinted with permission from [96] 1998 Elsevier. 


\section{Structure, Phase Composition, Mechanical and Tribological Properties of Some Multilayer Coatings}

Structural features, physical-mechanical and tribological properties of multilayer structures can be reviewed in detail on the refractory and transition metals ( $\mathrm{Ti}, \mathrm{Cr}, \mathrm{Zr}$ and Mo) based nitride coatings $[2,10,29,82,108,118,119]$. TiN/ZrN, TiN/MoN and CrN/MoN coatings were deposited on the steel substrates by the vacuum-arc evaporation method $[8,99,100,120]$. The vacuum chamber was equipped with a pressure control system and two evaporators with $\mathrm{Ti}, \mathrm{Cr}$ or Mo targets. The automatic rotation system of the substrate holder provided the correct position of the substrates during the deposition process of each layer and the subsequent 180 degrees rotation to another evaporator. For instance, in case of TiN/ZrN coatings, nitrides of titanium and zirconium were deposited in accordance with the position of the holder relative to a certain cathode. After the deposition of one TiN layer the process stopped, the substrate holder was rotated $180^{\circ}$ and the deposition of the next $\mathrm{ZrN}$ layer started. Therefore, repetition of this process many times allowed obtaining multilayer TiN/ZrN coatings. The pressure of the nitrogen in a chamber $\left(P_{\mathrm{N}}\right)$, the bias voltage applied to the substrate $\left(U_{\mathrm{b}}\right)$ and the deposition time $(t)$ were the key parameters that influenced properties and structure of the vacuum-arc coatings [121,122].

Transmission electron microscopy (TEM) images of cross sections of the TiN/ZrN multilayer coatings (bilayer thickness of about $40 \mathrm{~nm}$ ) fabricated at -150 and $-200 \mathrm{~V}$ demonstrate a good planarity of the layers that do not intersect and are characterized by homogeneity without droplet inclusions inside the layers and between them (Figure 7) [123]. Figure 8 shows XRD pattern and selected area electron diffraction (SAED) image of TiN/ZrN sample with $\Lambda=39 \mathrm{~nm}$ deposited at $U_{\mathrm{b}}=-200 \mathrm{~V}$. According to the results, coatings consist of TiN and $\mathrm{ZrN}$ phases with $\mathrm{NaCl}$-type cubic crystal structure. They are highly structured with crystallite sizes of about 10-20 nm [99,118,123]. TiN/MoN coatings had high hardness value about $34.5 \mathrm{GPa}$. Multilayer architecture resulted in the enhanced hardness compared to the single-layer TiN and $\mathrm{ZrN}$ coatings that demonstrated $28 \pm 0.5$ and $22.7 \pm 1.7 \mathrm{GPa}$, respectively $[123,124]$. According to the results of the tribological tests, TiN/ZrN coatings did not crack, chip or deform under the load. Specific wear rate of the sample and the counterbody $\left(\mathrm{Al}_{2} \mathrm{O}_{3}\right.$ ball) were about $(1.3-1.5) \times 10^{-2} \mathrm{~mm}^{3} \cdot \mathrm{N}^{-1} \cdot \mathrm{m}^{-1}$ and $(1.9-2.2) \times 10^{-3} \mathrm{~mm}^{3} \cdot \mathrm{N}^{-1} \cdot \mathrm{m}^{-1}$, respectively. The friction coefficient was found to be approximately $1.2[99,123]$. Hence, TiN/ZrN multilayer systems demonstrate high hardness and resistance to wear, which indicates they can be successfully applied as protective coatings.

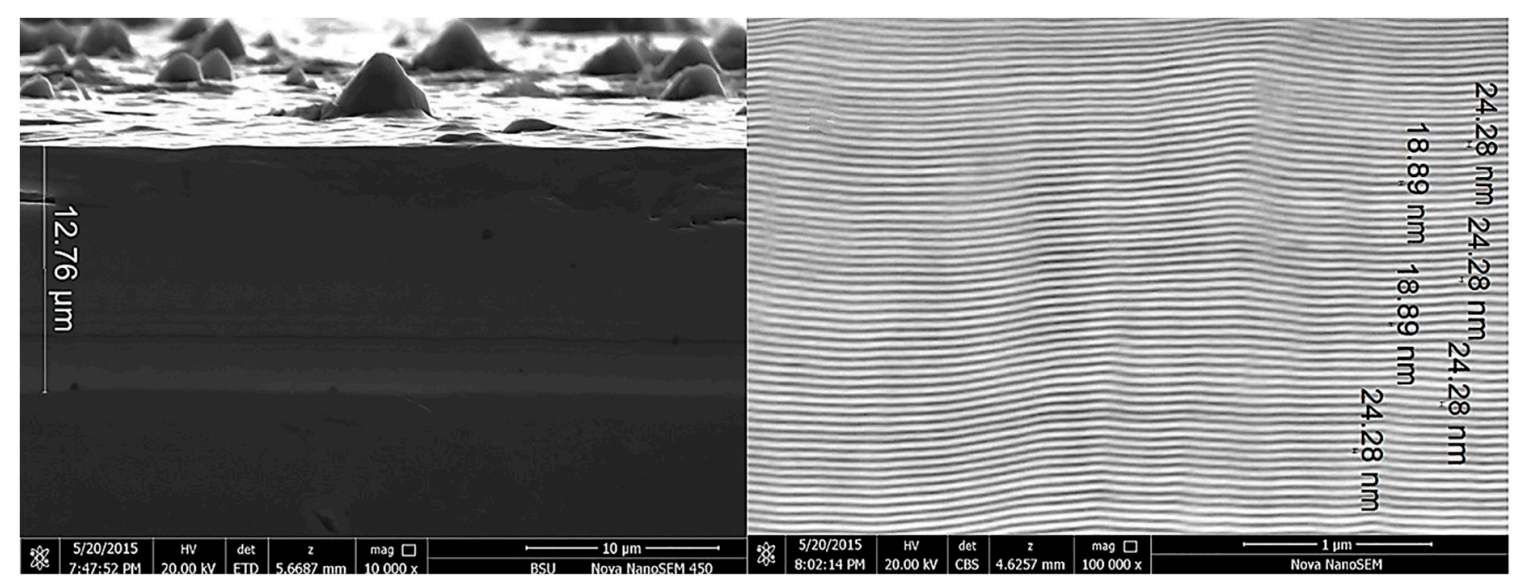

Figure 7. Cross sectional TEM images of TiN/ZrN multilayer coatings with modulation periods of about $40 \mathrm{~nm}$ deposited at $U_{\mathrm{b}}=-150 \mathrm{~V}$ [123]. 


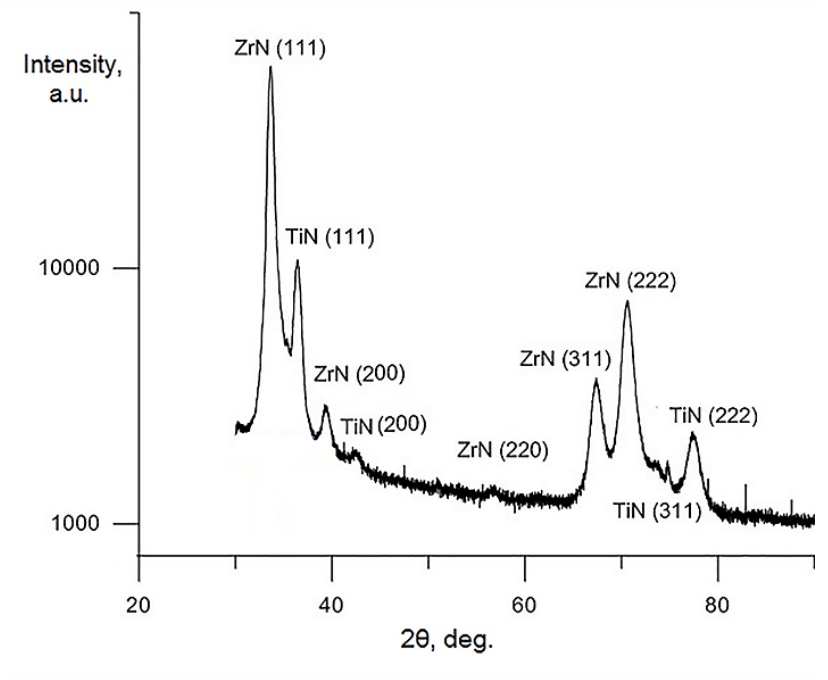

(a)

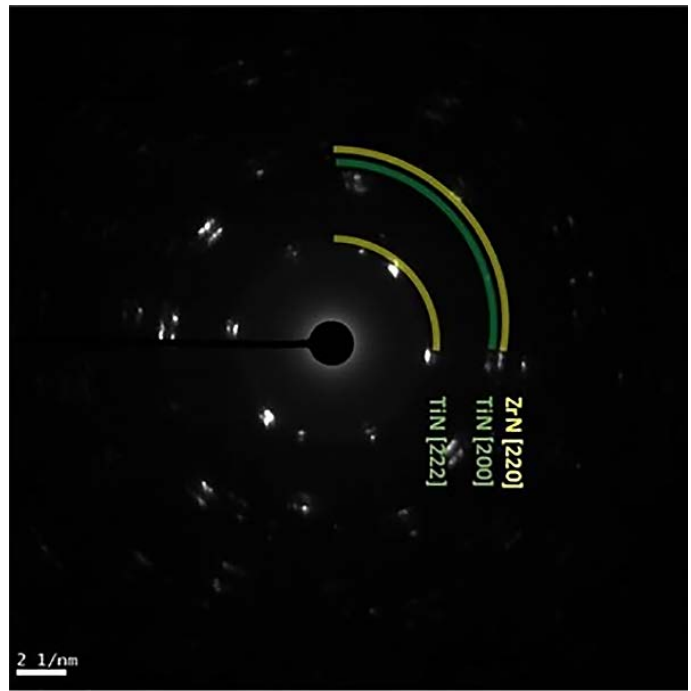

(b)

Figure 8. (a) X-ray diffraction (XRD) spectrum and (b) Selected area electron diffraction (SAED) image of TiN/ZrN multilayer coatings $\left(U_{\mathrm{b}}=-200 \mathrm{~V}, \Lambda=39 \mathrm{~nm}\right)$. Reprinted with permission from [99] 2017 Elsevier.

$\mathrm{CrN} / \mathrm{MoN}$ coatings with different bilayer thickness deposited at $-20,-150$ and $-300 \mathrm{~V}$ are another example of multilayer structures based on transition metals [100]. SEM images CrN/MoN coatings deposited at $U_{\mathrm{b}}=-20 \mathrm{~V}$ demonstrate a multilayer structure with distinct and definite boundaries of individual layers (Figure 9). However, the thickness of MoN layers (light colour) was slightly less than that of CrN layers (dark colour) that was confirmed by TEM studies of CrN/MoN samples with $\Lambda=72 \mathrm{~nm}$ deposited at the substrate bias of $-300 \mathrm{~V}$ (Figure 10). The same situation was observed in TiN/MoN multilayer coatings fabricated at $U_{\mathrm{b}}=-40 \mathrm{~V}$. Their cross section views are depicted in Figure 11, where the light lines correspond to MoN and the dark ones correspond to TiN layers $[120,125]$. It may be caused by different time evaporation of cathodes and deposition rates of nitride layers [126]. TEM studies of TiN/MoN coatings showed a growth of the columnar structure (Figure 12). The structure consisted of the sequence of alternating TiN and MoN layers, and the well-crystallized $100 \mathrm{~nm}$ thin interlayer, which contained Ti, Mo, C, and N [101].

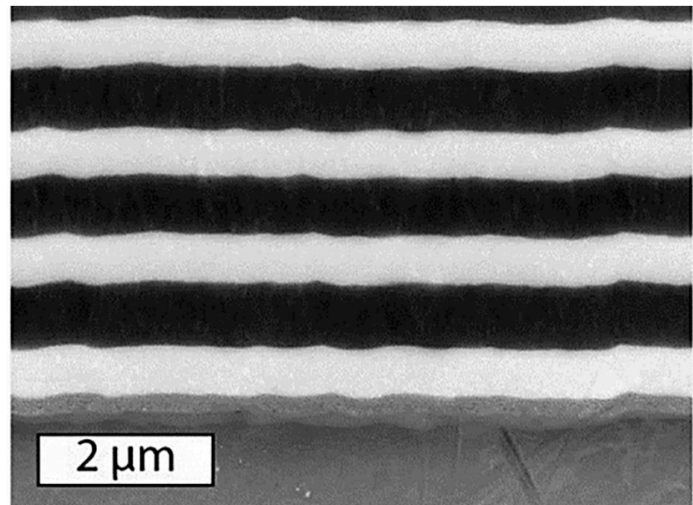

(a)

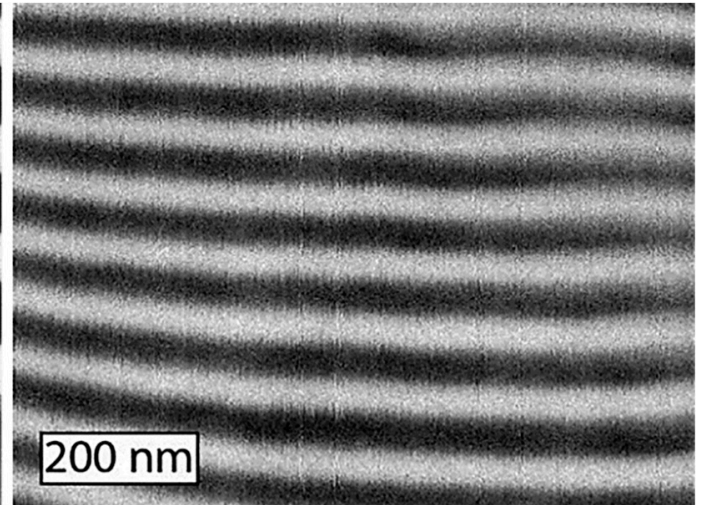

(b)

Figure 9. SEM images of $\mathrm{CrN} / \mathrm{MoN}$ coatings with bilayer thickness of (a) $1.18 \mu \mathrm{m}$ and (b) $44 \mathrm{~nm}$. Reprinted with permission from [126] 2017 Elsevier. 


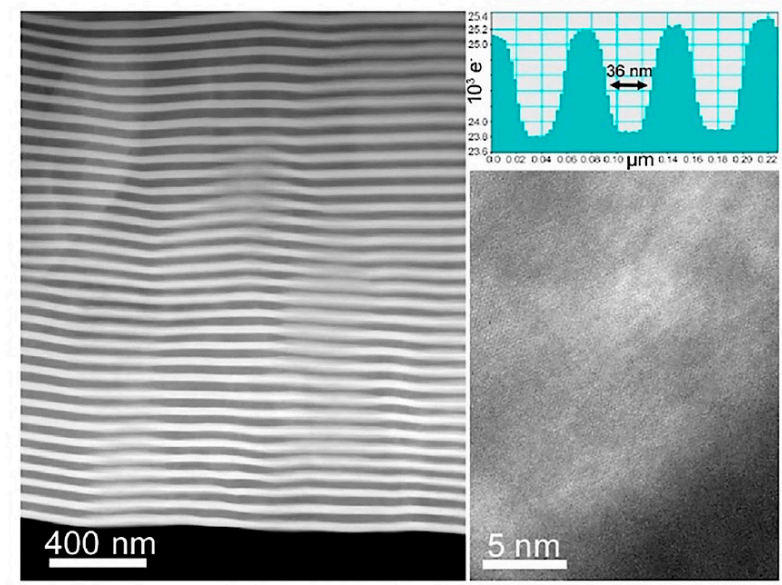

(a)

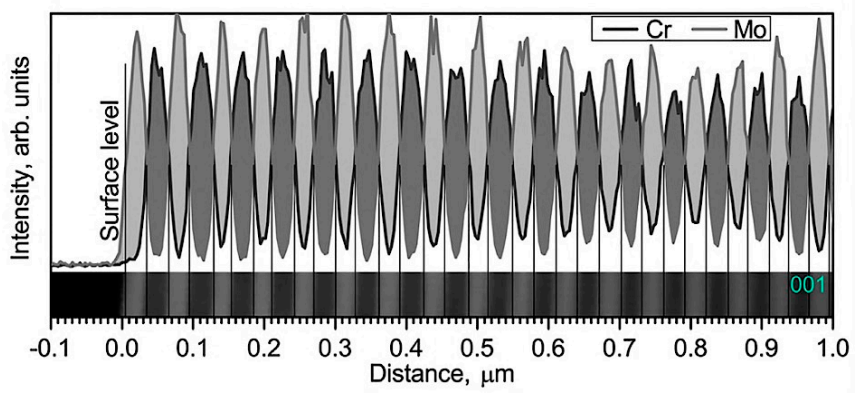

(b)

Figure 10. (a)TEM images and (b) elemental depth profile ( $\mathrm{Cr}, \mathrm{Mo}$ ) with corresponding TEM cross-section view of the $\mathrm{CrN} / \mathrm{MoN}$ coatings with bilayer thickness of $75 \mathrm{~nm}$. Reprinted with permission from [100] 2018 Elsevier.

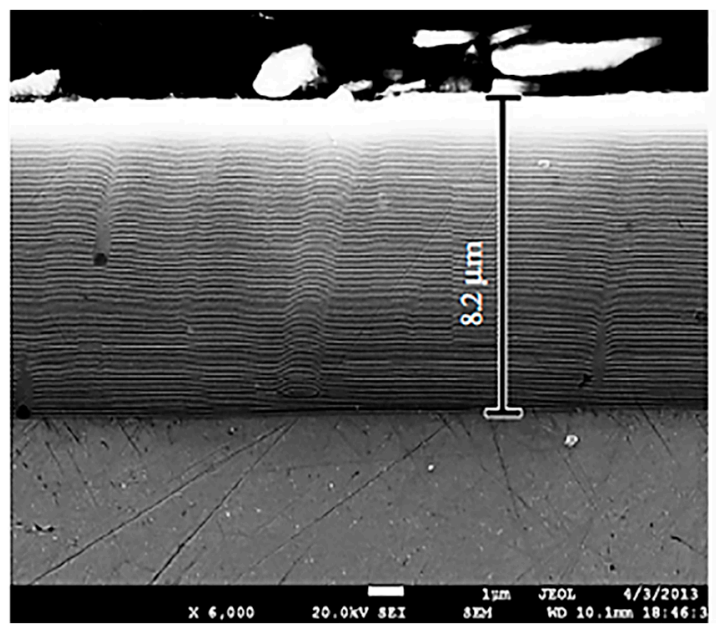

(a)

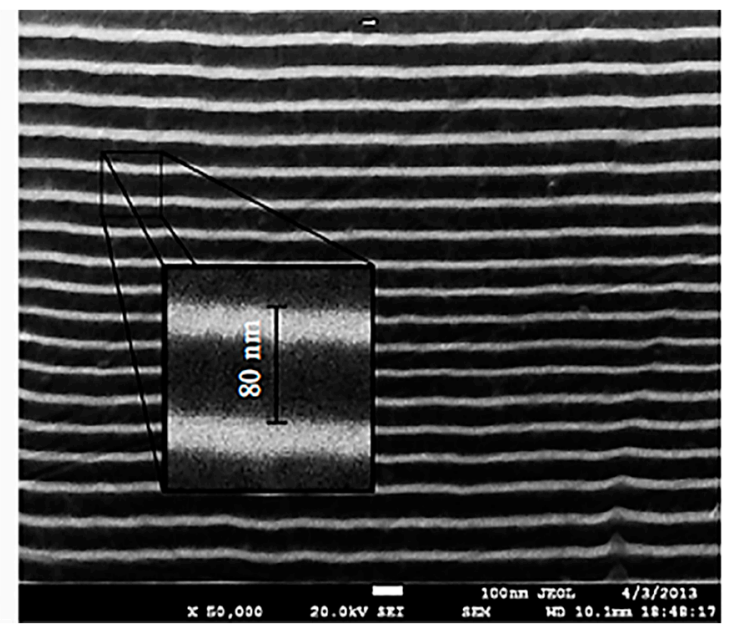

(b)

Figure 11. Cross sectional SEM images of the TiN/MoN coatings: (a) general view and (b) $50000 \times$ magnification. Reprinted with permission from [127] 2015 Springer. 


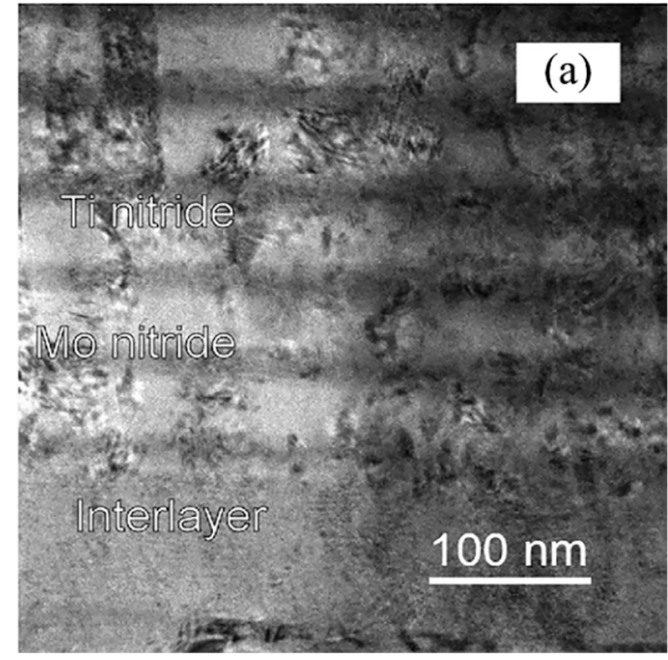

(a)

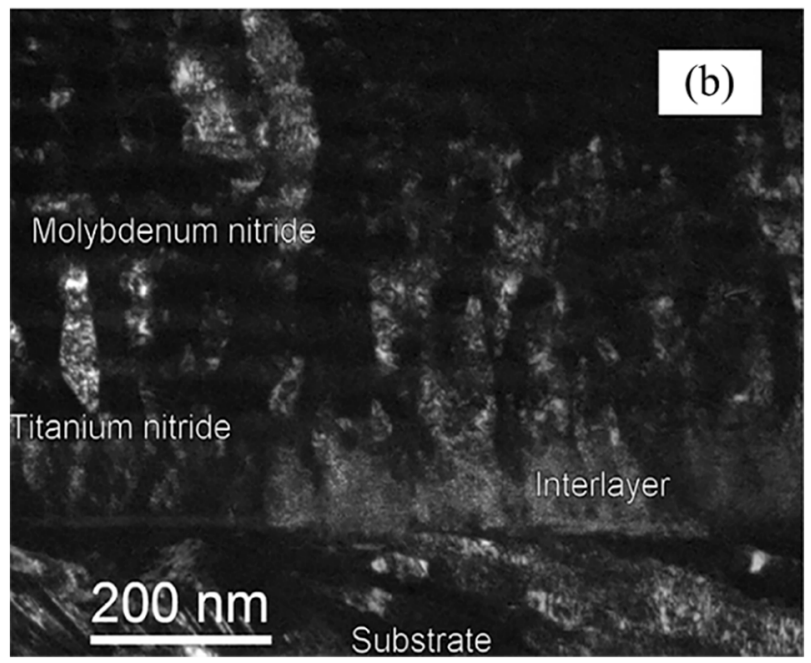

(b)

Figure 12. TEM bright-field (a) and dark-field (b) images of the TiN/MoN multilayer coatings with an average bilayer thickness of about $50 \mathrm{~nm}$. Reprinted with permission from [101] 2015 Elsevier.

The change in the bias voltage applied to the substrate from -20 to $-300 \mathrm{~V}$ sufficiently affected the structure of $\mathrm{CrN} / \mathrm{MoN}$ coatings (Figure 13). Overall, all series of samples had two phases with fcc lattice- $\mathrm{CrN}$ and $\mathrm{Mo}_{2} \mathrm{~N}$. Although, results of XRD analysis showed changes in the preferred orientation. At $U_{\mathrm{b}}=-20 \mathrm{~V}$ the [311] texture could be recognized. Increasing the bias voltage to $-150 \mathrm{~V}$ led to the formation of the [111] texture and the solid solution $(\mathrm{Cr}, \mathrm{Mo}) \mathrm{N}$ at interfaces between layers. Applying the highest bias voltage $(-300 \mathrm{~V})$ resulted in the [200]-oriented structure due to the relative decrease of the nitrogen content $[100,126,128,129]$. Peak shift towards lower angles indicated residual stresses, which might be caused by the deposition conditions, as well as the differences in thermal expansion coefficients and temperature of the substrate and the coating during the fabrication process $[130,131]$. SAED pattern of the $\mathrm{CrN} / \mathrm{MoN}$ coatings with bilayer thickness of about $75 \mathrm{~nm}$ $\left(U_{\mathrm{b}}=-300 \mathrm{~V}\right)$ was in a good agreement with XRD analysis and indicated $\mathrm{CrN}(111), \mathrm{CrN}(220)$ and $\mathrm{MoN}$ (200) phases. Furthermore, crystallite sizes were approximately $12 \mathrm{~nm}$ and microstrain was about $0.4 \%-0.5 \%$ [100].

Nanoscale multilayer structure endow coatings with high mechanical properties. The hardness values of $\mathrm{CrN} / \mathrm{MoN}$ coatings reached $39 \mathrm{GPa}$ at small bias voltage of $-20 \mathrm{~V}$ and the individual layer thickness less that $60 \mathrm{~nm}$ (Figure 14). However, some samples of this series showed even higher hardness, $42.3 \mathrm{GPa}$. It may be caused by the reduction in the grain size, the increase in the number of interphases and the amplification of the Hall-Petch effect that prevents the movement of dislocations. Further increase in the substrate bias voltage and the layer thickness resulted in decrease of the hardness. Nevertheless, coatings deposited at $U_{\mathrm{b}}=-300 \mathrm{~V}$ showed a reverse trend-the higher layer thickness the higher hardness. 


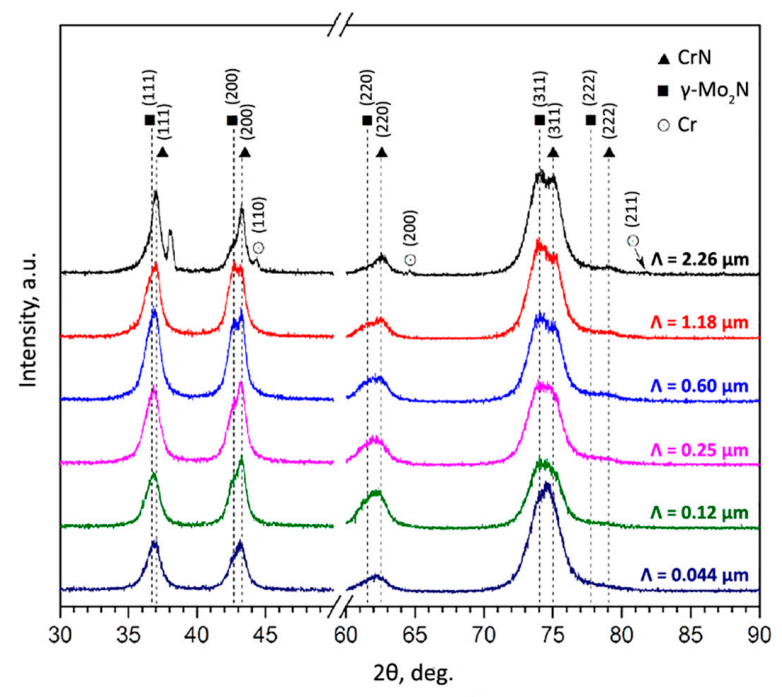

(a)

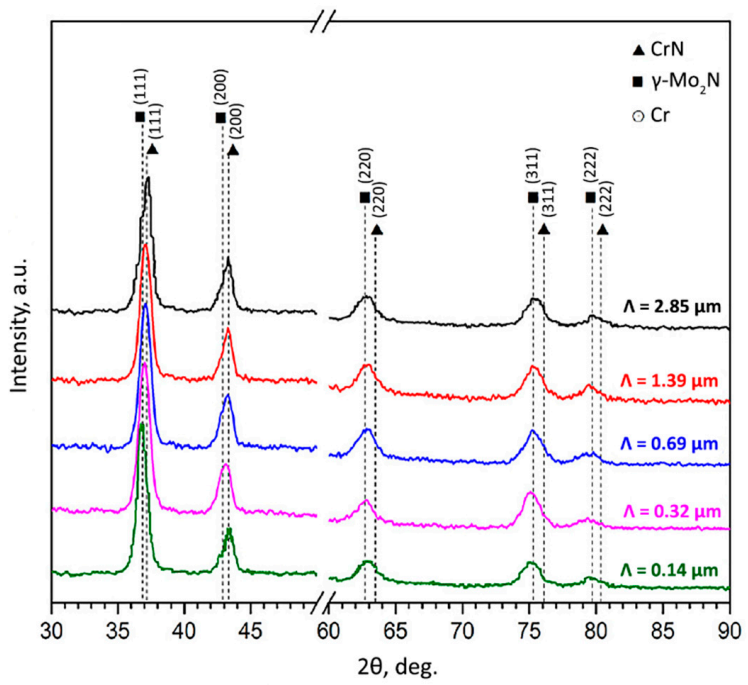

(b)

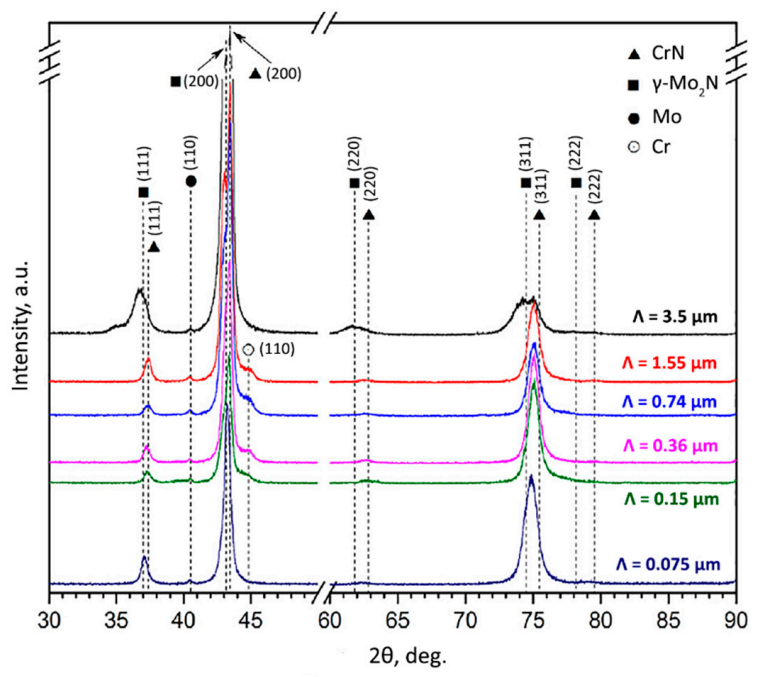

(c)

Figure 13. XRD patterns for $\mathrm{CrN} / \mathrm{MoN}$ coatings deposited at different bias voltage: (a) $-20 \mathrm{~V}$; (b) $-150 \mathrm{~V}$; (c) -300 V. Reprinted with permission from [100] 2018 Elsevier. 


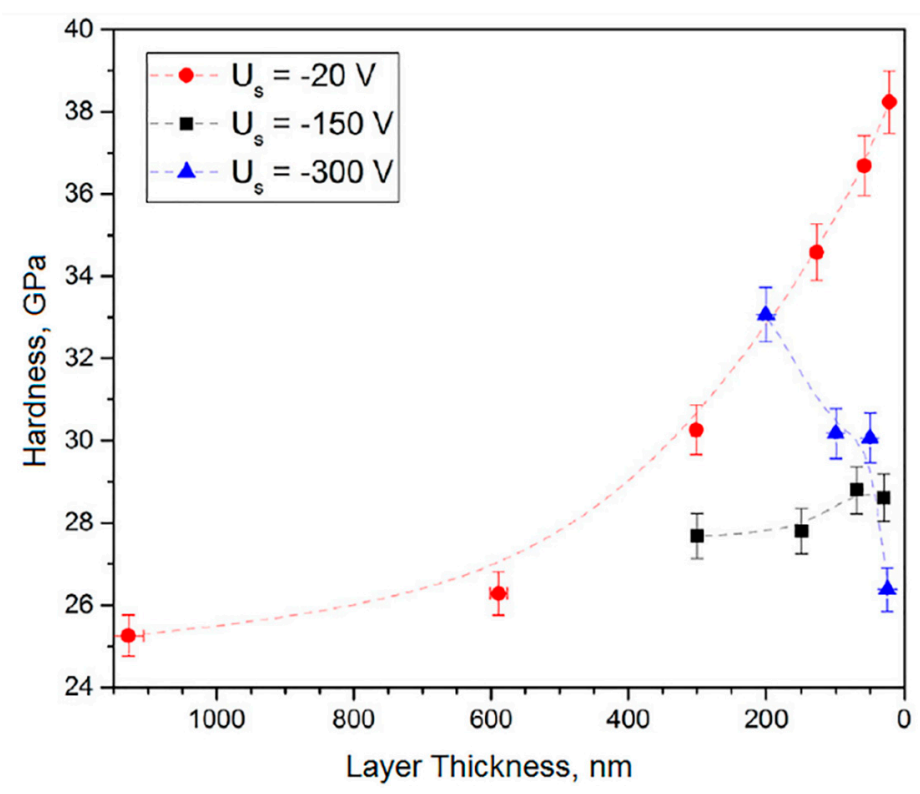

Figure 14. Dependence of the hardness on the layer thickness for $\mathrm{CrN} / \mathrm{MoN}$ coatings deposited at different bias voltage. Reprinted with permission from [100] 2018 Elsevier.

Moreover, CrN/MoN samples with bilayer thickness of about $44 \mathrm{~nm}$ deposited at $U_{\mathrm{b}}=-20 \mathrm{~V}$ showed the lowest wear during tribological tests. The friction coefficient was approximately 0.44 . Specific wear rate of the coating and the counterbody were $5.92 \times 10^{-7}$ and $0.89 \times 10^{-7} \mathrm{~mm}^{3} \cdot \mathrm{N}^{-1} \cdot \mathrm{m}^{-1}$, respectively. The wear process was characterized by the transfer of the coating material from the surface to the corundum counterbody, the uniform abrasion and the symmetrical profile of the wear track [100,132-134]. Increase in the substrate bias voltage led to decrease in the wear resistance that can be seen in the Figure 15d. Figure 15a-c demonstrates profilograms of the wear tracks of the CrN/MoN coatings with different bilayer thickness deposited at $U_{\mathrm{b}}=-20 \mathrm{~V}$. The lowest wear was observed in the films with the smallest bilayer thickness that as described above had the highest hardness. Thus, multilayer architecture contributed to the improvement of properties. Interlayer boundaries changed their direction of propagation of the generated microcracks and localized deformations near the surface $[100,135]$.

The microstructure investigation of the different series of TiN/MoN coatings with bilayer thickness of 25, 50 and $100 \mathrm{~nm}$ revealed two peaks that correspond to TiN (111) at 36.5 , TiN (200) and $\gamma-\mathrm{Mo}_{2} \mathrm{~N}$ (200) phases at 42.5 degrees [101,136] (Figure 16). Even though during vacuum-arc evaporation two modifications of molybdenum nitride are expected to be formed $\left(\right.$ fcc $\gamma-\mathrm{Mo}_{2} \mathrm{~N}$ and tetragonal $\beta-\mathrm{Mo}_{2} \mathrm{~N}$ ), only cubic structure was developed. At the initial stage of deposition, small difference in the lattice parameters of TiN and $\gamma-\mathrm{Mo}_{2} \mathrm{~N}$ as well as the sequence of atoms in TiN basal lattice contributed to the growth of cubic type of molybdenum nitride [127]. XRD- $\sin ^{2} \psi$ method used to determine the residual stress in titanium nitride layers showed they are compressed in (200) and (311) planes; the level of stress was measured to be from -6 to $-5 \mathrm{GPa}$. It is common for arc-evaporated coatings due to the intensive ion bombardment of the surface during the deposition process [101,137]. 


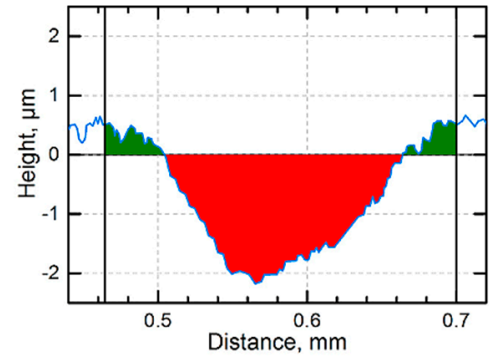

(a)

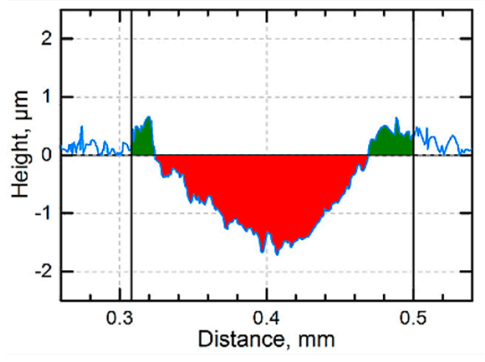

(b)

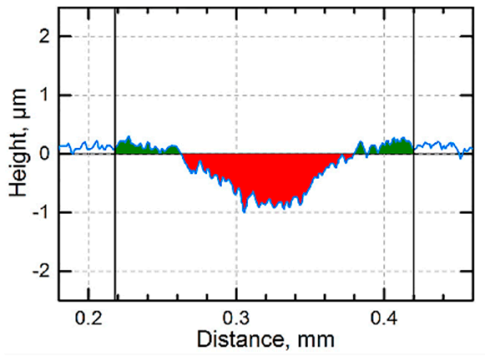

(c)

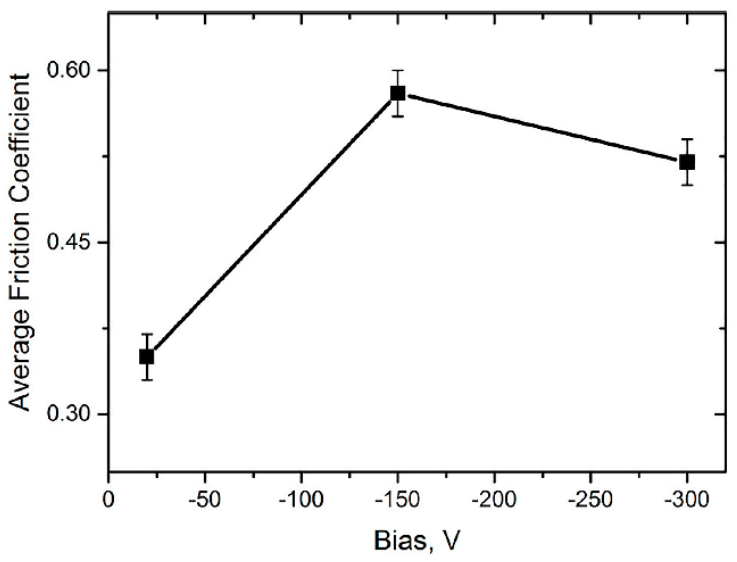

(d)

Figure 15. Results of tribological investigation of $\mathrm{CrN} / \mathrm{MoN}$ multilayer coatings: $(\mathbf{a}-\mathbf{c})$ profilograms of the wear tracks during tribological test with $\mathrm{Al}_{2} \mathrm{O}_{3}$ counterbody for samples with bilayer thickness of $0.6 \mu \mathrm{m}, 0.25 \mu \mathrm{m}$ and $44 \mathrm{~nm}$, respectively; (d) dependence of the average friction coefficient on the bias voltage applied to the substrate. Reprinted with permission from [100] 2018 Elsevier.

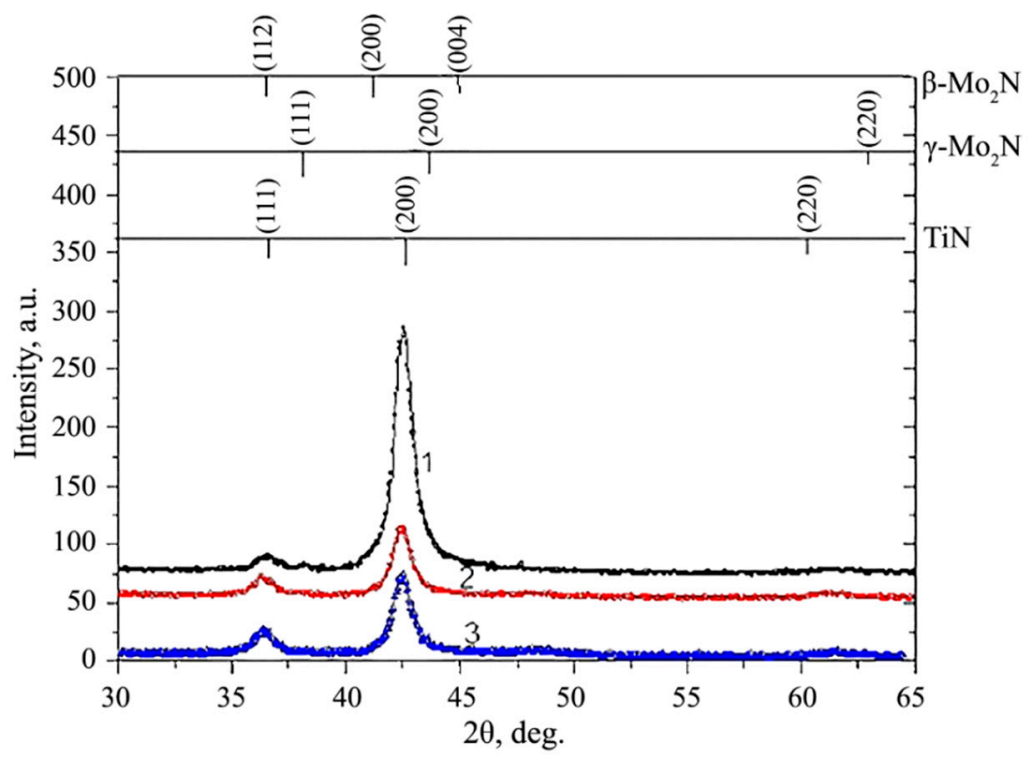

Figure 16. XRD pattern of the TiN/MoN coatings with different modulation period deposited at $U_{\mathrm{b}}=-40 \mathrm{~V}$ : (1) $25 \mathrm{~nm}$; (2) $50 \mathrm{~nm}$; (3) $100 \mathrm{~nm}$. Reprinted with permission from [101] 2015 Elsevier.

TiN/MoN coatings demonstrated enhanced hardness up to $30 \mathrm{GPa}$ at the optimal bilayer thickness of about $25 \mathrm{~nm}$, which is approximately $25 \%$ higher than the hardness of the corresponding single-layer 
coatings. An increase and a reduction in the modulation period led to the decrease in its value to approximately $26 \mathrm{GPa}$ [125]. Results of the tribological tests showed that the friction coefficient for TiN/MoN was in the range of 0.09-0.12. Moreover, the highest critical load $\left(L_{3}\right)$, at which the destruction of coatings begins, attained the value of about $64.8 \mathrm{~N}$. The lowest specific wear rates of the coating and the $\mathrm{Al}_{2} \mathrm{O}_{3}$ counterbody were measured to be $2.33 \times 10^{-2}$ and $0.15 \times 10^{-2} \mathrm{~mm}^{3} \cdot \mathrm{N}^{-1} \cdot \mathrm{m}^{-1}$, respectively. Such high results were observed for structures with the thinnest bilayers, at $\Lambda=25 \mathrm{~nm}$. However, increase in the modulation period caused a decrease of these parameters. It may be explained by the fact that at small bilayer thickness, nanograins are surrounded by single nitride that prevents shift of the grain boundaries and, therefore, strengthens the nanocomposite $[101,138]$.

Thus, all multilayer $\mathrm{TiN} / \mathrm{MoN}, \mathrm{TiN} / \mathrm{ZrN}$ and $\mathrm{CrN} / \mathrm{MoN}$ coatings, due to intense ion bombardment during deposition process, had a two-phase structure and consisted of the corresponding nitrides with $\mathrm{NaCl}$-type lattice with the preferential [111] orientation and the grain size of about 5-30 $\mathrm{nm}$. Structure and deposition conditions had a significant impact on mechanical and tribological properties. The best results were observed when the bilayer thickness was in a range of 40-60 nm. The loss of barrier properties due to the intensification of mixing processes of high-energy particles near interfaces could be the main reason of the hardness reduction at $\Lambda<40 \mathrm{~nm}$. CrN/MoN coatings with $\Lambda=44 \mathrm{~nm}$ exhibited the highest hardness of about 38-42 GPa, which indicated a superhard state, the lowest friction coefficient and specific wear rate. However, applying higher substrate bias voltage and changing the optimal bilayer thickness decreased hardness.

The relationship between mechanical and tribological properties of $\mathrm{CrN} / \mathrm{TiN}$ multilayer superlattice coatings were comprehensively studied in Ref. [98]. Generally, coatings with higher values of $\mathrm{H} / \mathrm{E}^{*}$ (parameter that is related to the plasticity of material) and $\mathrm{H}^{3} / \mathrm{E}^{* 2}$ (resistance to plastic deformation) demonstrate enhanced critical loads, wear-resistance and elastic contact during "ball-on-disc" sliding tests [139-141]. The CrN/TiN films with optimal bilayer thickness of $6.3 \mathrm{~nm}$ were characterized by fcc crystalline structure with a strong [111] texture, fine grain size of about $30 \mathrm{~nm}$ and the best mechanical and tribological properties (Figure 17). They possessed the highest hardness of about $36 \mathrm{GPa}, \mathrm{H} / \mathrm{E}^{*}$ and $\mathrm{H}^{3} / \mathrm{E}^{*} 2$ ratios (Figure 17b). Enhanced hardness and toughness, dense microstructure and optimal bilayer thickness resulted in the low wear as coefficient of friction was 0.27 and specific wear rate was reduced to $0.5 \times 10^{-6} \mathrm{~mm}^{3} \cdot \mathrm{N}^{-1} \mathrm{~m}^{-1}$ (Figure 14a) $[98,119,142,143]$. Predominant wear mechanism in CrN/TiN coatings with $\Lambda=6.3 \mathrm{~nm}$ was a mild abrasive wear [98]. Hence, the correlation between microstructure, mechanical and tribological properties can be clearly seen.

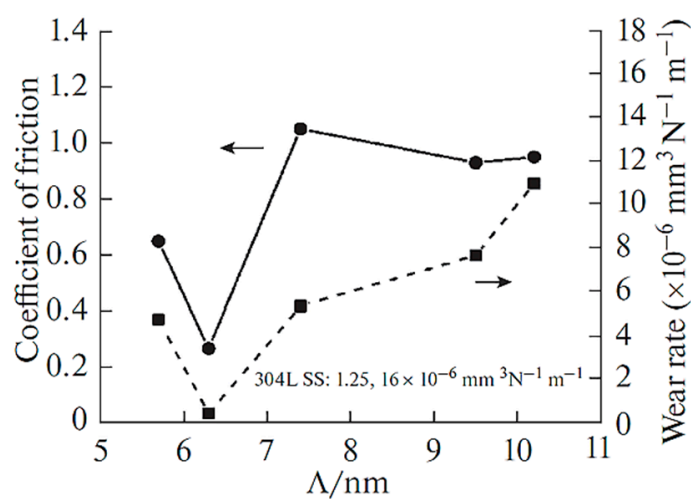

(a)

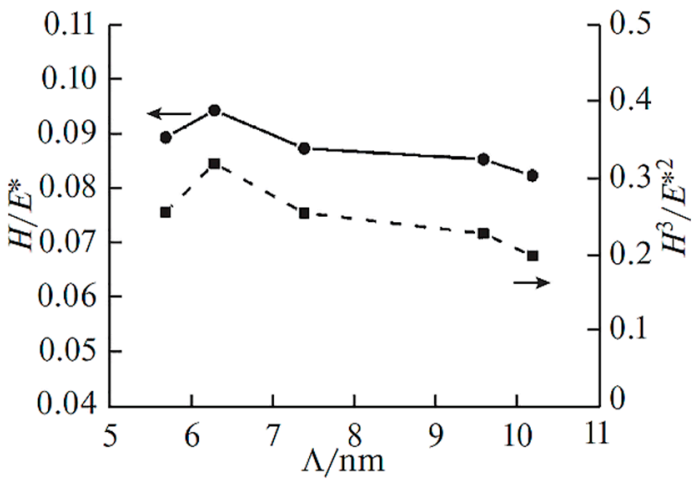

(b)

Figure 17. Friction coefficient and specific wear rate $(\mathbf{a}), \mathrm{H} / \mathrm{E}^{*}$ and $\mathrm{H}^{3} / \mathrm{E}^{* 2}$ ratios $(\mathbf{b})$ as a function of the bilayer thickness of CrN/TiN multilayer superlattice coatings. Reprinted with permission from [142] 2018 Springer Nature. 
Besides mechanical and wear properties, corrosion behaviour is another important characteristic of the film material that determines its service life expectancy. Therefore, studying the corrosion resistance of coatings can provide us with essential information on the possibility of their working under severe oxidizing conditions [144]. For example, corrosion behaviour was investigated in detail on the multilayer $\mathrm{CrN} / \mathrm{ZrN}$ nanostructured coatings with 1, 8, 15 and 30 bilayers deposited on steel substrates by the radio frequency magnetron sputtering [145]. Changing the number of bilayers allowed to determine their impact on the rate of corrosion. Surface roughness and, as expected, friction coefficient showed almost linear descending dependence with increasing the number of bilayers. Thus, $\mathrm{CrN} / \mathrm{ZrN}$ coatings with 30 bilayers demonstrated the highest coefficient of friction of about 0.33 and were expected to have the lowest corrosion rate. Electrochemical analysis in 3.5\% $\mathrm{NaCl}$ solution was performed to obtain the Tafel polarization curves that bear information about the corrosion resistance (Figure 18) [146,147]. Results of electrochemical analysis indicated an abrupt improvement in the corrosion behaviour with increase in the number of bilayers. Uncoated stainless steel substrate had corrosion rate of $0.316 \mathrm{~mm} \cdot \mathrm{year}^{-1}$, deposition of one bilayer of alternating $\mathrm{CrN}$ and ZrN single-layers enhanced it parameter to $5.611 \times 10^{-2} \mathrm{~mm} \cdot$ year $^{-1}$ and 30 bilayers demonstrated the best corrosion behaviour-2.048 $\times 10^{-4} \mathrm{~mm} \cdot \mathrm{year}^{-1}$ [145].

Recently, some works have reported high characteristics of the multilayer structures consisting of transition metal nitrides and silicon carbide, which is also widely demanded in different branches of industry [148-151]. For example, the TiN/SiC multilayer coatings were comprehensively studied in Ref. [152]. They were deposited by DC magnetron sputtering at $U_{\mathrm{b}}=-50 \mathrm{~V}$ and varied temperatures of the substrate $\left(T_{\mathrm{s}}\right)$ over the range $25-350{ }^{\circ} \mathrm{C}$ in order to investigate possible changes in structure and properties of the samples. Grazing incident X-ray diffraction (GIXRD) analysis of the TiN/SiC samples showed structure transformations depending on the substrate temperature (Figure 19). When $T_{\mathrm{S}}$ was 25 and $100^{\circ} \mathrm{C}$, films consisted of nanocrystalline (nc) TiN layers with small grains surrounded by the amorphous silicon carbide layers. Increasing substrate temperature up to 200 and $350{ }^{\circ} \mathrm{C}$ resulted in the formation of the nc-TiN/nc-SiC multilayer structure with small grain size of about $3.35 \pm 0.5 \mathrm{~nm}$ and drastic increase in the Knoop hardness and nanohardness up to 53 and 32-34 GPa, respectively (Figure 20) [152]. It should be noted that TiN/SiC multilayer coatings demonstrated much higher values of hardness compared to those of TiN (30 GPa) and SiC (27 GPa) single-layers with similar thickness.

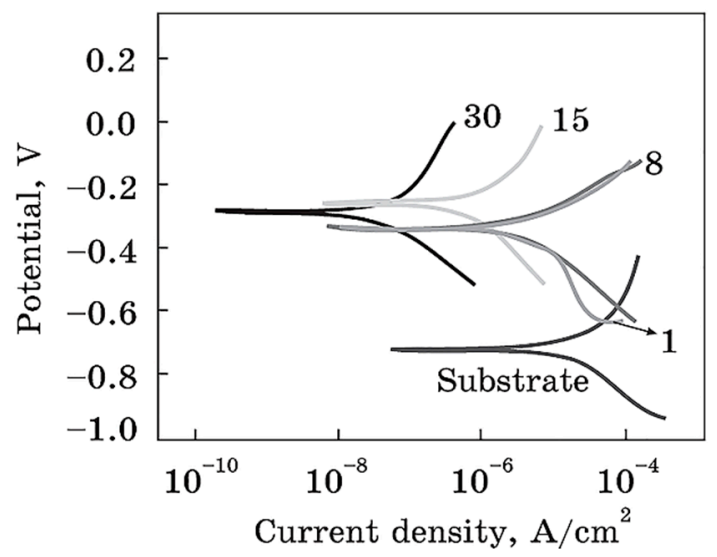

Figure 18. Cathodic and anodic Tafel polarization curves for $\mathrm{CrN} / \mathrm{ZrN}$ multilayer coatings with different number of bilayers $(1,8,15,30)$ [147]. 


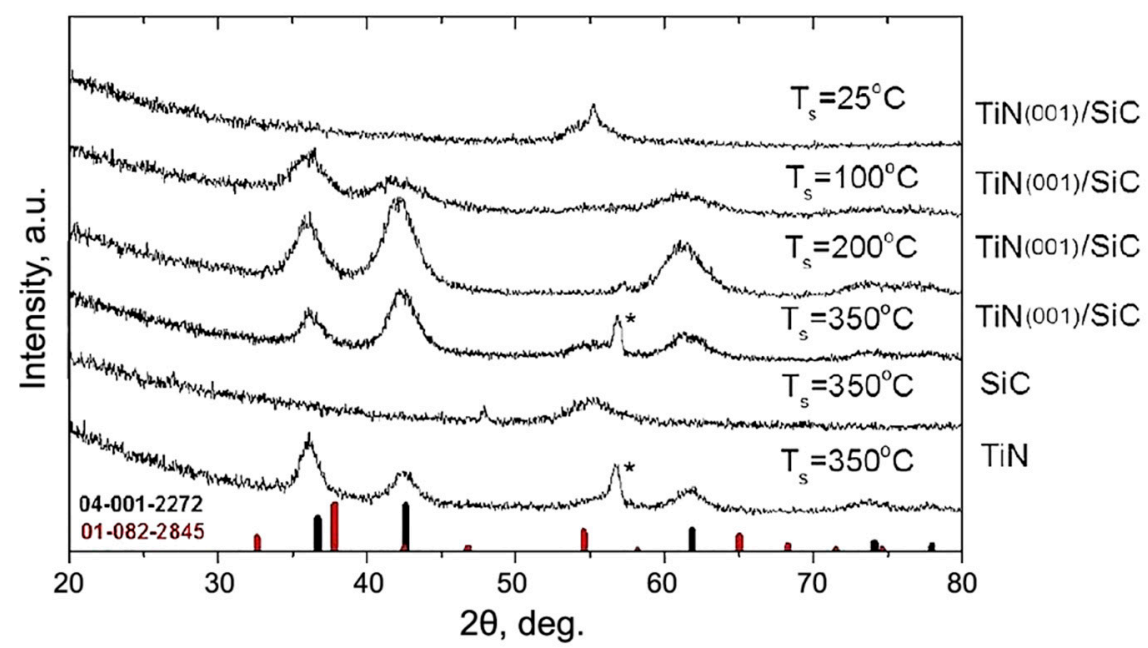

Figure 19. GIXRD patterns for multilayer TiN/SiC films deposited at different substrate temperature from 25 to $350{ }^{\circ} \mathrm{C}$ and single-layer $\mathrm{SiC}$ and TiN films obtained at $T_{\mathrm{S}}=350{ }^{\circ} \mathrm{C}$. Red and black lines are consistent with $\mathrm{SiC}$ and TiN films, respectively; ${ }^{*}$ indicates a hexagonal phase. Reprinted with permission from [152] 2018 Elsevier.

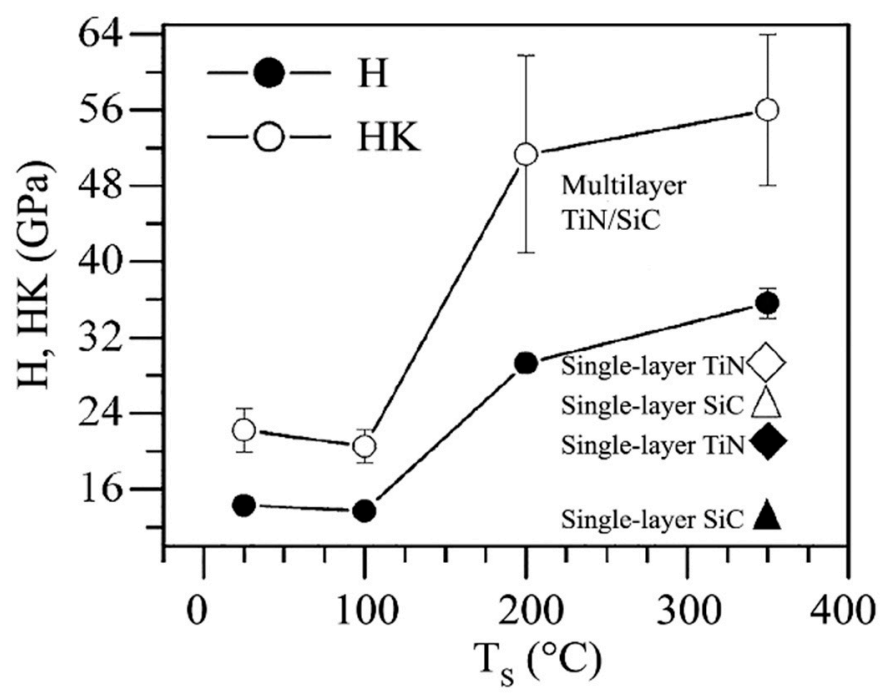

Figure 20. Dependence of the Knoop hardness $(\mathrm{HK})$ and the nanohardness $(\mathrm{H})$ of the multilayer $\mathrm{TiN} / \mathrm{SiC}$ films and the single-layer TiN and SiC films on the substrate temperature. Reprinted with permission from [152] 2018 Elsevier.

In order to complement the results of research, authors implemented the first-principles molecular dynamics computation of TiN(001)/SiC heterostructure using Quantum ESPRESSO-integrated suite of computer codes [152,153]. They investigated the structure of the $\mathrm{TiN}(001) / \mathrm{SiC}$ interface. Four heterostructures were simulated. The first two were B1 heterostructure equilibrated at $300 \mathrm{~K}$ and then relaxed and B3, equilibrated at $1200 \mathrm{~K}$, slowly cooled to $300 \mathrm{~K}$ and relaxed. Then crystallized SiC was replaced by amorphous silicon carbide ( $\mathrm{a}-\mathrm{SiC}$ ) by heating the sample to up $4500 \mathrm{~K}$, its equilibration, cooling to $300 \mathrm{~K}$ and subsequent relaxation. Thus, another two interphases had TiN(001)/a-SiC structure: A0 that was equilibrated at $300 \mathrm{~K}$ and relaxed and A1 equilibrated at $1200 \mathrm{~K}$, slowly cooled to $300 \mathrm{~K}$ and relaxed. These heterostructures generated at different temperatures were investigated for better understanding the ways to improve the strength of TiN/SiC films. Atomic configurations at the initial state and after failure as a result of elongation are depicted in Figure 21. The rock salt $\mathrm{B} 1$ and the amorphous A0 heterostructures after heating underwent transformation into B3 and A1 
ones with cubic 3C-SiC-like interfaces, respectively [152,154]. Taking into account the stress-tensile strain relations from Figure 22, there was concluded that the weakest interphase was A0 (ideal tensile strength, $\sigma_{\mathrm{T}}$, was $\left.8 \mathrm{GPa}\right)$ and the most stable one-three-layer $3 \mathrm{C}-\mathrm{SiC}\left(\sigma_{\mathrm{T}}=17 \mathrm{GPa}\right.$ and $\left.11 \mathrm{GPa}\right)$. Hence, experimental and theoretical data correlate with each other. Elevated temperatures resulted in the formation of the 3C-SiC-like interphases in the TiN/SiC film, which were responsible for the strengthening [152].

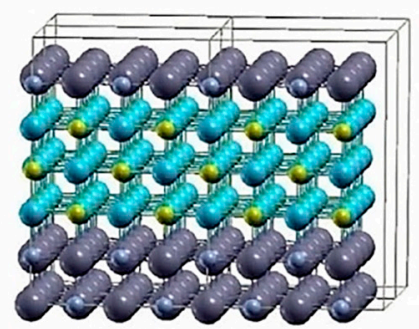

$\mathrm{B} 1, \varepsilon=0.0$

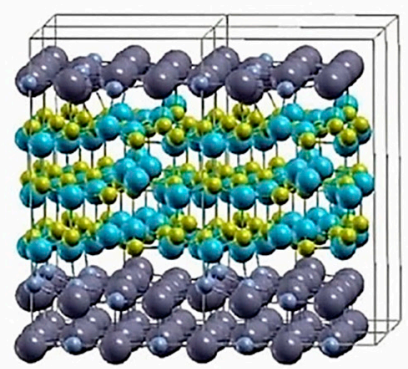

Bl, $\varepsilon=0.16$

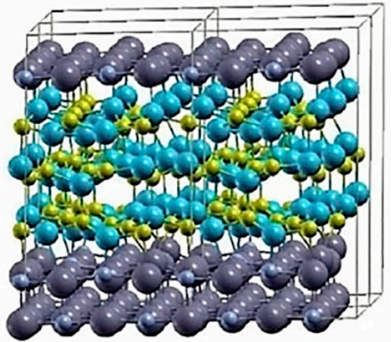

B3, $\varepsilon=0.0$

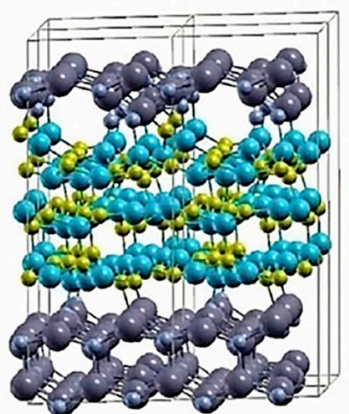

B3, $\varepsilon=0.32$

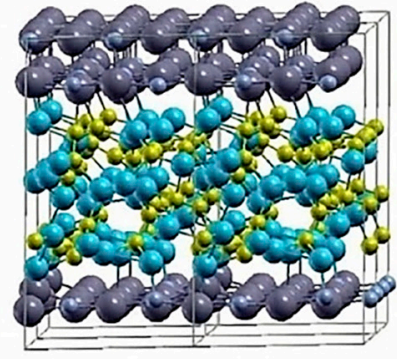

Al, $\varepsilon=0.0$

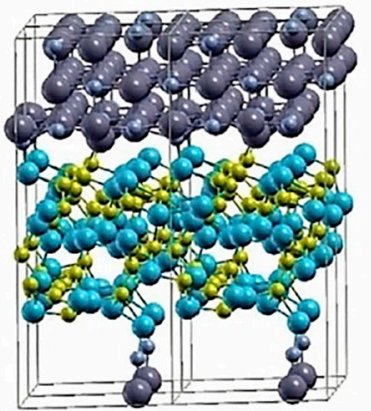

$\mathrm{Al}, \varepsilon=0.28$

Figure 21. Atomic configurations of the $\mathrm{TiN}(001) / \mathrm{SiC}$ heterostructures prior elongation (top row) and just after failure (bottom row). Reprinted with permission from [152] 2018 Elsevier.

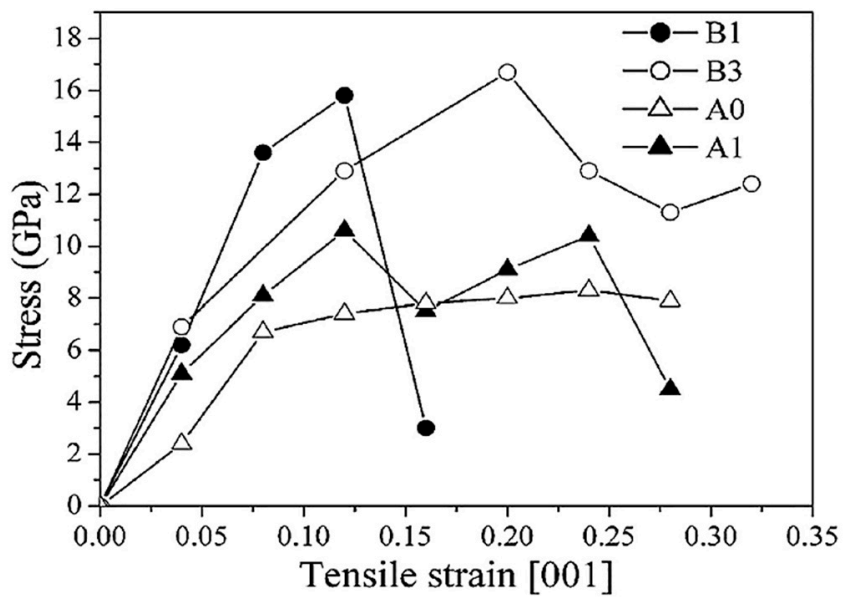

Figure 22. Stress-tensile strain curves of the $\mathrm{TiN}(001) / \mathrm{SiC}$ heterostructures simulated at different conditions. Reprinted with permission from [152] 2018 Elsevier.

All multilayer systems, considered in the present brief review, demonstrated high mechanical and tribological properties. Hence, these hard coatings can withstand extreme conditions and are perspective candidates for wide range of applications in different branches of industry. 


\section{Conclusions}

In this paper, we reviewed nanostructured multilayer coatings based on binary nitrides of transition and refractory metals deposited by magnetron sputtering and vacuum-arc evaporation (PVD techniques). It should be note that using a multilayer architecture allows to design coatings with unique properties that are not inherent in the single-layer coatings. Alternating layers of nitrides with different characteristics, it is possible to obtain a universal material that could have numerous various applications in engineering, manufacturing and many other industrial fields. Several factors that strongly influence their performance characteristics have been described. Tuning the substrate bias voltage controls the deposition rate of the growing multilayer material that significantly affect the microstructure. It is crucial to deposit coatings with well-defined multilayer structure with high density, small grain size and optimum bilayer thickness of the order of tens nanometres. It provides high volume of boundary interfaces and big number of interfaces between layers that contributes to hindering the dislocation mobility. Furthermore, heating the substrate during the deposition process can also results in the increment of hardness, when amorphous phase transforms into nanocrystalline. Reviewed papers demonstrated that binary multilayer coatings based on transition metals nitrides could exhibit superhardness (hardness $\geq 40 \mathrm{GPa}$ ), high plasticity, corrosion resistance and low wear. Therefore, combination of these properties enables them to operate for a long time in extreme working conditions, such as oxidizing environment, high temperature and pressure.

Multilayer coatings can be further improved by the integration of new nanocrystalline, nanocomposite or amorphous materials as constituent layers. Another way to enhance performance characteristics of the multilayer architecture is a use of nitrides consisting of more than one metal, for instance TiAlN/CrAlN, CrAlYN/CrN, TiHfN/CrN and so forth.

It is worth mentioned, that we did not pay attention to the problem of number of constituent elements in the composition of individual layers within our brief review. However, multilayer coatings based on binary nitrides of refractory or transition metals, are the basis for future investigations of more complicated structures based on triple or even quaternary nitrides. Thus, full investigation of more simple materials allows to predict peculiarities of structure, texture, physical-mechanical and tribological properties of more complex coatings.

Funding: This work was supported by the Ministry of Education and Science of Ukraine within the state budget programs entitled "Multilayer and multicomponent coatings with adaptive behaviour under friction and wear" (registration number 0118U003579) and "Implantation of high-energy and low-energy ions into multilayer and multicomponent coatings: microstructure and properties" (registration number 0119U100787).

Conflicts of Interest: The authors declare no conflict of interest. The funders had no role in the design of the study; in the collection, analyses, or interpretation of data; in the writing of the manuscript, or in the decision to publish the results.

\section{References}

1. Koltunowicz, T.N.; Zhukowski, P.; Fedotov, A.K.; Larkin, A.V.; Patryn, A.; Andryevskyy, B.; Saad, A.; Fedotova, J.A.; Fedotova, V.V. Influence of Matrix Type on Negative Capacitance Effect in Nanogranular Composite Films FeCoZr-Insulator. Elektron. IR Elektrotechnika 2013, 19, 37-40. [CrossRef]

2. Barshilia, H.C.; Jain, A.; Rajam, K.S. Structure, Hardness and Thermal Stability of Nanolayered TiN/CrN Multilayer Coatings. Vacuum 2003, 72, 241-248. [CrossRef]

3. Holmberg, K.; Matthews, A.; Ronkainen, H. Coatings Tribology—Contact Mechanisms and Surface Design. Tribol. Int. 1998, 31, 107-120. [CrossRef]

4. PalDey, S.; Deevi, S.C. Single Layer and Multilayer Wear Resistant Coatings of (Ti,Al)N: A Review. Mater. Sci. Eng. A 2003, 342, 58-79. [CrossRef]

5. Jehn, H.A. Multicomponent and Multiphase Hard Coatings for Tribological Applications. Surf. Coat. Technol. 2000, 131, 433-440. [CrossRef] 
6. Andreeva, D.V.; Skorb, E.V. Chapter 13-Multi-Layer Smart Coatings for Corrosion Protection of Aluminium Alloys and Steel. In Handbook of Smart Coatings for Materials Protection; Makhlouf, A.S.H., Ed.; Woodhead Publishing: Sawston, UK, 2014; pp. 307-327. [CrossRef]

7. Makhlouf, A.S.H. Chapter 6-Protective Coatings for Automotive, Aerospace and Military Applications: Current Prospects and Future Trends. In Handbook of Smart Coatings for Materials Protection; Makhlouf, A.S.H., Ed.; Woodhead Publishing: Sawston, UK, 2014; pp. 121-131. [CrossRef]

8. Beresnev, V.M.; Bondar, O.V.; Postolnyi, B.O.; Lisovenko, M.O.; Abadias, G.; Chartier, P.; Kolesnikov, D.A.; Borisyuk, V.N.; Mukushev, B.A.; Zhollybekov, B.R.; et al. Comparison of Tribological Characteristics of Nanostructured TiN, MoN and TiN/MoN Arc-PVD Coatings. J. Frict. Wear 2014, 35, 374-382. [CrossRef]

9. Khadem, M.; Penkov, O.V.; Yang, H.-K.; Kim, D.-E. Tribology of Multilayer Coatings for Wear Reduction: A Review. Friction 2017, 5, 248-262. [CrossRef]

10. Guan, X.; Wang, Y.; Zhang, G.; Jiang, X.; Wang, L.; Xue, Q. Microstructures and Properties of Zr/CrN Multilayer Coatings Fabricated by Multi-Arc Ion Plating. Tribol. Int. 2017, 106, 78-87. [CrossRef]

11. Cheng, Y.H.; Browne, T.; Heckerman, B.; Bowman, C.; Gorokhovsky, V.; Meletis, E.I. Mechanical and Tribological Properties of TiN/Ti Multilayer Coating. Surf. Coat. Technol. 2010, 205, 146-151. [CrossRef]

12. Ma, F.; Li, J.; Zeng, Z.; Gao, Y. Structural, Mechanical and Tribocorrosion Behaviour in Artificial Seawater of CrN/AlN Nano-Multilayer Coatings on F690 Steel Substrates. Appl. Surf. Sci. 2018, 428, 404-414. [CrossRef]

13. Pogrebnjak, A.D.; Bagdasaryan, A.A.; Yakushchenko, I.V.; Beresnev, V.M. The Structure and Properties of High-Entropy Alloys and Nitride Coatings Based on Them. Russ. Chem. Rev. 2014, 83, 1027. [CrossRef]

14. Pogrebnyak, A.D.; Shpak, A.P.; Azarenkov, N.A.; Beresnev, V.M. Structures and Properties of Hard and Superhard Nanocomposite Coatings. Phys.-Uspekhi 2009, 52, 29. [CrossRef]

15. Vereschaka, A.; Tabakov, V.; Grigoriev, S.; Sitnikov, N.; Oganyan, G.; Andreev, N.; Milovich, F. Investigation of Wear Dynamics for Cutting Tools with Multilayer Composite Nanostructured Coatings in Turning Constructional Steel. Wear 2019, 420-421, 17-37. [CrossRef]

16. Kindlund, H.; Sangiovanni, D.G.; Martínez-de-Olcoz, L.; Lu, J.; Jensen, J.; Birch, J.; Petrov, I.; Greene, J.E.; Chirita, V.; Hultman, L. Toughness Enhancement in Hard Ceramic Thin Films by Alloy Design. APL Mater. 2013, 1, 042104. [CrossRef]

17. Boing, D.; de Oliveira, A.J.; Schroeter, R.B. Limiting Conditions for Application of PVD (TiAlN) and CVD (TiCN/Al2O3/TiN) Coated Cemented Carbide Grades in the Turning of Hardened Steels. Wear 2018, 416-417, 54-61. [CrossRef]

18. Ahmad, Z. Chapter 1-Introduction to Corrosion. In Principles of Corrosion Engineering and Corrosion Control; Ahmad, Z., Ed.; Butterworth-Heinemann: Oxford, UK, 2006; pp. 1-8. [CrossRef]

19. Bagdasaryan, A.A.; Pshyk, A.V.; Coy, L.E.; Konarski, P.; Misnik, M.; Ivashchenko, V.I.; Kempiński, M.; Mediukh, N.R.; Pogrebnjak, A.D.; Beresnev, V.M.; et al. A New Type of (TiZrNbTaHf)N/MoN Nanocomposite Coating: Microstructure and Properties Depending on Energy of Incident Ions. Compos. Part B Eng. 2018, 146, 132-144. [CrossRef]

20. Barshilia, H.C.; Deepthi, B.; Rajam, K.S. Chapter 10-Transition Metal Nitride-Based Nanolayered Multilayer Coatings and Nanocomposite Coatings as Novel Superhard Materials. In Nanostructured Thin Films and Coatings: Mechanical Properties; CRC Press: Boca Raton, FL, USA, 2010; pp. 427-480.

21. Gaffney, J.S.; Marley, N.A. Chapter 3-Chemical Bonding-The Formation of Materials. In General Chemistry for Engineers; Gaffney, J.S., Marley, N.A., Eds.; Elsevier: Amsterdam, The Netherlands, 2018; pp. 75-116. [CrossRef]

22. Needham, P. The Source of Chemical Bonding. Stud. Hist. Philos. Sci. Part A 2014, 45, 1-13. [CrossRef]

23. Nilsson, A.; Pettersson, L.G.M. Chapter 2-Adsorbate Electronic Structure and Bonding on Metal Surfaces. In Chemical Bonding at Surfaces and Interfaces; Nilsson, A., Pettersson, L.G.M., Nørskov, J.K., Eds.; Elsevier: Amsterdam, The Netherlands, 2008; pp. 57-142. [CrossRef]

24. Stephanos, J.J.; Addison, A.W. Chapter 3-Chemical Bonding. In Electrons, Atoms and Molecules in Inorganic Chemistry; Stephanos, J.J., Addison, A.W., Eds.; Academic Press: Cambridge, MA, USA, 2017; pp. 147-226. [CrossRef]

25. Weber, M.; Iatsunskyi, I.; Coy, E.; Miele, P.; Cornu, D.; Bechelany, M. Novel and Facile Route for the Synthesis of Tunable Boron Nitride Nanotubes Combining Atomic Layer Deposition and Annealing Processes for Water Purification. Adv. Mater. Interfaces 2018, 5, 1800056. [CrossRef] 
26. Weber, M.; Coy, E.; Iatsunskyi, I.; Yate, L.; Miele, P.; Bechelany, M. Mechanical Properties of Boron Nitride Thin Films Prepared by Atomic Layer Deposition. CrystEngComm 2017, 19, 6089-6094. [CrossRef]

27. Pierson, H.O. Handbook of Refractory Carbides and Nitrides: Properties, Characteristics, Processing and Applications; Noyes publications: Westwood, NJ, USA, 1996.

28. Mayrhofer, P.H.; Mitterer, C.; Clemens, H. Self-Organized Nanostructures in Hard Ceramic Coatings. Adv. Eng. Mater. 2005, 7, 1071-1082. [CrossRef]

29. Holleck, H.; Schier, V. Multilayer PVD Coatings for Wear Protection. Surf. Coat. Technol. 1995, 76-77, 328-336. [CrossRef]

30. Wai-Kee, L.; Gong-Du, Z.; Thomas, S.W.M. Advanced Structural Inorganic Chemistry; Oxford University Press Inc.: New York, NY, USA, 2008.

31. Rasaki, S.A.; Zhang, B.; Anbalgam, K.; Thomas, T.; Yang, M. Synthesis and Application of Nano-Structured Metal Nitrides and Carbides: A Review. Prog. Solid State Chem. 2018, 50, 1-15. [CrossRef]

32. Othmer, K. Kirk-Othmer Encyclopedia of Chemical Technology, 5th ed.; Wiley-Interscience: Hoboken, NJ, USA, 2006.

33. Dong, S.; Chen, X.; Zhang, X.; Cui, G. Nanostructured Transition Metal Nitrides for Energy Storage and Fuel Cells. Coord. Chem. Rev. 2013, 257, 1946-1956. [CrossRef]

34. Salamat, A.; Hector, A.L.; Kroll, P.; McMillan, P.F. Nitrogen-Rich Transition Metal Nitrides. Coord. Chem. Rev. 2013, 257, 2063-2072. [CrossRef]

35. Samsonolf, G.V.; Pryadko, I.F.; Pryadko, L.F. A Configurational Model of Matter, 1st ed.; Tybulewicz, A., Translator; Consultants Bureau: New York, NY, USA, 1973.

36. Dong, H. Tribological Properties of Titanium-Based Alloys. In Surface Engineering of Light Alloys: Aluminium, Magnesium and Titanium Alloys; Woodhead Publishing Limited: Cambridge, MA, USA, 2010; pp. 58-82.

37. Voznyi, A.; Kosyak, V.; Opanasyuk, A.; Tirkusova, N.; Grase, L.; Medvids, A.; Mezinskis, G. Structural and Electrical Properties of SnS2 Thin Films. Mater. Chem. Phys. 2016, 173, 52-61. [CrossRef]

38. Pogrebnjak, A.D.; Bagdasaryan, A.A.; Pshyk, A.; Dyadyura, K. Adaptive Multicomponent Nanocomposite Coatings in Surface Engineering. Phys.-Uspekhi 2017, 60, 586. [CrossRef]

39. Kurbatov, D.; Opanasyuk, A.; Khlyap, H. Substrate-Temperature Effect on the Microstructural and Optical Properties of ZnS Thin Films Obtained by Close-Spaced Vacuum Sublimation. Phys. Status Solidi A 2009, 206, 1549-1557. [CrossRef]

40. Żukowski, P.; Koltunowicz, T.N.; Bondariev, V.; Fedotov, A.K.; Fedotova, J.A. Determining the Percolation Threshold for (FeCoZr)x(CaF2)(100-x) Nanocomposites Produced by Pure Argon Ion-Beam Sputtering. J. Alloy. Compd. 2016, 683, 62-66. [CrossRef]

41. Hashmi, S. Comprehensive Materials Processing, 1st ed.; Elsevier: Amsterdam, The Netherlands, 2014.

42. Toth, L.E. Transition Metal Carbides and Nitrides, 1st ed.; Academic Press: New York, NY, USA, 1971.

43. Goldschmidt, H.J. Interstitial Alloys, 1st ed.; Butterworth-Heinemann: Oxford, UK, 1967.

44. Pogrebnjak, A.D.; Beresnev, V.M.; Smyrnova, K.V.; Kravchenko, Y.O.; Zukowski, P.V.; Bondarenko, G.G. The Influence of Nitrogen Pressure on the Fabrication of the Two-Phase Superhard Nanocomposite (TiZrNbAlYCr)N Coatings. Mater. Lett. 2018, 211, 316-318. [CrossRef]

45. Holleck, H. Material Selection for Hard Coatings. J. Vac. Sci. Technol. A 1986, 4, 2661-2669. [CrossRef]

46. Goltsman, G.; Korneev, A.; Izbenko, V.; Smirnov, K.; Kouminov, P.; Voronov, B.; Kaurova, N.; Verevkin, A.; Zhang, J.; Pearlman, A.; et al. Nano-Structured Superconducting Single-Photon Detectors. Nucl. Instrum. Methods Phys. Res. Sect. Accel. Spectrom. Detect. Assoc. Equip. 2004, 520, 527-529. [CrossRef]

47. Kerman, A.J.; Dauler, E.A.; Keicher, W.E.; Yang, J.K.W.; Berggren, K.K.; Gol'tsman, G.; Voronov, B. Kinetic-Inductance-Limited Reset Time of Superconducting Nanowire Photon Counters. Appl. Phys. Lett. 2006, 88, 111116. [CrossRef]

48. Bitauld, D.; Marsili, F.; Fiore, A.; Gaggero, A.; Mattioli, F.; Leoni, R.; Benkahoul, M.; Lévy, F. NbN Nanowire Superconducting Single Photon Detectors Fabricated on MgO Substrates. J. Mod. Opt. 2009, 56, 395-400. [CrossRef]

49. Villégier, J.-C.; Delaet, B.; Feautrier, P.; Frey, L.; Delacour, C.; Bouchiat, V. Fabrication of High-Speed Single Photon Detectors in NbN for Quantum Information Processing. J. Phys. Conf. Ser. 2006, 43, 1373. [CrossRef]

50. Semenov, A. Hot-Electrons in Superconducting Nanostructures for Detection of Terahertz Radiation. Cryogenics 2009, 49, 656-659. [CrossRef]

51. Gol'tsman, G.N.; Gershenzon, E.M. Phonon-Cooled Hot-Electron Bolometric Mixer: Overview of Recent Results. Appl. Supercond. 1999, 6, 649-655. [CrossRef] 
52. Żukowski, P.; Kołtunowicz, T.; Partyka, J.; Fedotova, Y.A.; Larkin, A.V. Electrical Properties of Nanostructures $(\mathrm{CoFeZr})_{x}+\left(\mathrm{Al}_{2} \mathrm{O}_{3}\right)_{1-x}$ with Use of Alternating Current. Vacuum 2009, 83, S275-S279. [CrossRef]

53. Stueber, M.; Holleck, H.; Leiste, H.; Seemann, K.; Ulrich, S.; Ziebert, C. Concepts for the Design of Advanced Nanoscale PVD Multilayer Protective Thin Films. J. Alloy. Compd. 2009, 483, 321-333. [CrossRef]

54. Bull, S.J.; Jones, A.M. Multilayer Coatings for Improved Performance. Surf. Coat. Technol. 1996, 78, $173-184$. [CrossRef]

55. Sakakima, H.; Osano, K.; Ihara, K.; Satomi, M. Multilayered Films of Nitride Alloys as Magnetic Head Materials. J. Magn. Magn. Mater. 1991, 93, 349-355. [CrossRef]

56. Wadsworth, I.; Smith, I.J.; Donohue, L.A.; Münz, W.-D. Thermal Stability and Oxidation Resistance of TiAlN/CrN Multilayer Coatings. Surf. Coat. Technol. 1997, 94-95, 315-321. [CrossRef]

57. Wang, M.X.; Zhang, J.J.; Yang, J.; Wang, L.Q.; Li, D.J. Influence of Ar/N2 Flow Ratio on Structure and Properties of Nanoscale ZrN/WN Multilayered Coatings. Surf. Coat. Technol. 2007, 201, 5472-5476. [CrossRef]

58. Sadki, E.S.; Barber, Z.H.; Lloyd, S.J.; Blamire, M.G.; Campbell, A.M. Effects of Interlayer Coupling on the Irreversibility Lines of NbN/AIN Superconducting Multilayers. Phys. Rev. Lett. 2000, 85, 4168-4171. [CrossRef] [PubMed]

59. Celis, J.-P.; Prakash, B. Surface Modification of Materials by Plasma Immersion Ion Implantation. In Materials Surface Processing by Directed Energy Techniques; Pauleau, Y., Ed.; Elsevier: Amsterdam, The Netherlands, 2006.

60. Vieira, T.; Castanho, J.; Louro, C. Hard Coatings Based on Metal Nitrides, Metal Carbides and Nanocomposite Materials: PVD Process and Properties. In Materials Surface Processing by Directed Energy Techniques; Pauleau, Y., Ed.; Elsevier: Amsterdam, The Netherlands, 2006.

61. Falco, C.M.; Slaughter, J.M. Characterization of Metallic Multilayers for X-Ray Optics. J. Magn. Magn. Mater. 1993, 126, 3-7. [CrossRef]

62. Gilewicz, A.; Warcholinski, B. Deposition and Characterisation of Mo2N/CrN Multilayer Coatings Prepared by Cathodic Arc Evaporation. Surf. Coat. Technol. 2015, 279, 126-133. [CrossRef]

63. Hultman, L. Thermal Stability of Nitride Thin Films. Vacuum 2000, 57, 1-30. [CrossRef]

64. Molina-Aldareguia, J.M.; Lloyd, S.J. Chapter 3-Multilayered Materials: A Palette for the Materials Artist. In Advances in Nanoengineering: Electronics, Materials and Assembly; Davies, A.G., Thompson, G.M.T., Eds.; World Scientific Publishing Co.: Singapore, 2007; Chapter 3.

65. Smallman, R.E.; Ngan, A.H.W. Chapter 10-Surfaces, Grain Boundaries and Interfaces. In Modern Physical Metallurgy (Eighth Edition); Smallman, R.E., Ngan, A.H.W., Eds.; Butterworth-Heinemann: Oxford, UK, 2014; pp. 415-442. [CrossRef]

66. Hogmark, S.; Jacobson, S.; Larsson, M. Design and Evaluation of Tribological Coatings. Wear 2000, 246, $20-33$. [CrossRef]

67. Holleck, H.; Schulz, H. Preparation and Behaviour of Wear-Resistant $\mathrm{TiC} / \mathrm{TiB}_{2}$, $\mathrm{TiN} / \mathrm{TiB}_{2}$ and $\mathrm{TiC} / \mathrm{TiN}$ Coatings with High Amounts of Phase Boundaries. Surf. Coat. Technol. 1988, 36, 707-714. [CrossRef]

68. Koehler, J.S. Attempt to Design a Strong Solid. Phys. Rev. B 1970, 2, 547-551. [CrossRef]

69. Zhang, S.; Sun, D.; Fu, Y.; Du, H. Toughening of Hard Nanostructural Thin Films: A Critical Review. Surf. Coat. Technol. 2005, 198, 2-8. [CrossRef]

70. Tjong, S.C.; Chen, H. Nanocrystalline Materials and Coatings. Mater. Sci. Eng. R. Rep. 2004, 45, 1-88. [CrossRef]

71. Inspektor, A.; Salvador, P.A. Architecture of PVD Coatings for Metalcutting Applications: A Review. Surf. Coat. Technol. 2014, 257, 138-153. [CrossRef]

72. Bagdasaryan, A.A.; Pshyk, A.V.; Coy, L.E.; Kempiński, M.; Pogrebnjak, A.D.; Beresnev, V.M.; Jurga, S. Structural and Mechanical Characterization of (TiZrNbHfTa)N/WN Multilayered Nitride Coatings. Mater. Lett. 2018, 229, 364-367. [CrossRef]

73. Chauhan, A.; Vaish, R. Hard Coating Material Selection Using Multi-Criteria Decision Making. Mater. Des. 2013, 44, 240-245. [CrossRef]

74. Kravchenko, Y.O.; Coy, L.E.; Peplińska, B.; Iatsunskyi, I.; Załęski, K.; Kempiǹski, M.; Beresnev, V.M.; Konarski, P.; Jurga, S.; Pogrebnjak, A.D. Nano-Multilayered Coatings of (TiAlSiY)N/MeN (Me=Mo, $\mathrm{Cr}$ and $\mathrm{Zr}$ ): Influence of Composition of the Alternating Layer on Their Structural and Mechanical Properties. J. Alloy. Compd. 2018, 767, 483-495. [CrossRef] 
75. Pogrebnjak, A.D.; Bondar, O.V.; Abadias, G.; Ivashchenko, V.; Sobol, O.V.; Jurga, S.; Coy, E. Structural and Mechanical Properties of $\mathrm{NbN}$ and Nb-Si-N Films: Experiment and Molecular Dynamics Simulations. Ceram. Int. 2016, 42, 11743-11756. [CrossRef]

76. Pogrebnjak, A.D.; Bagdasaryan, A.A.; Beresnev, V.M.; Nyemchenko, U.S.; Ivashchenko, V.I.; Kravchenko, Y.O.; Shaimardanov, Z.K.; Plotnikov, S.V.; Maksakova, O. The Effects of Cr and Si Additions and Deposition Conditions on the Structure and Properties of the (Zr-Ti-Nb)N Coatings. Ceram. Int. 2017, 43, 771-782. [CrossRef]

77. Macías, H.A.; Yate, L.; Coy, L.E.; Olaya, J.J.; Aperador, W. Effect of Nitrogen Flow Ratio on Microstructure, Mechanical and Tribological Properties of TiWSiNx Thin Film Deposited by Magnetron Co-Sputtering. Appl. Surf. Sci. 2018, 456, 445-456. [CrossRef]

78. Zhou, Y.; Asaki, R.; Soe, W.-H.; Yamamoto, R.; Chen, R.; Iwabuchi, A. Hardness Anomaly, Plastic Deformation Work and Fretting Wear Properties of Polycrystalline TiN/CrN Multilayers. Wear 1999, 236, $159-164$. [CrossRef]

79. Yashar, P.C.; Sproul, W.D. Nanometer Scale Multilayered Hard Coatings. Vacuum 1999, 55, $179-190$. [CrossRef]

80. Vieira, M.T.; Ramos, A.S. The Influence of Ductile Interlayers on the Mechanical Performance of Tungsten Nitride Coatings. J. Mater. Process. Technol. 1999, 92-93, 156-161. [CrossRef]

81. Berger, M.; Wiklund, U.; Eriksson, M.; Engqvist, H.; Jacobson, S. The Multilayer Effect in Abrasion-Optimising the Combination of Hard and Tough Phases. Surf. Coat. Technol. 1999, 116-119, 1138-1144. [CrossRef]

82. Maksakova, O.V.; Simoẽs, S.; Pogrebnjak, A.D.; Bondar, O.V.; Kravchenko, Y.O.; Koltunowicz, T.N.; Shaimardanov, Z.K. Multilayered ZrN/CrN Coatings with Enhanced Thermal and Mechanical Properties. J. Alloy. Compd. 2019, 776, 679-690. [CrossRef]

83. Mattox, D.M. Handbook of Physical Vapor Deposition (PVD) Processing, 2nd ed.; Elsevier: Amsterdam, The Netherlands, 2010.

84. Singh, J.; Wolfe, D.E. Nanostructured Component Fabrication by Electron Beam-Physical Vapor Deposition. J. Mater. Eng. Perform. 2005, 14, 448-459. [CrossRef]

85. Schintlmeister, W.; Wallgram, W.; Kanz, J.; Gigl, K. Cutting Tool Materials Coated by Chemical Vapour Deposition. Wear 1984, 100, 153-169. [CrossRef]

86. Stephenson, D.A.; Agapiou, J.S. Metal Cutting Theory and Practice, 3rd ed.; CRC Press: Boca Raton, FL, USA, 2016.

87. Yang, S.; Li, X.; Cooke, K.E.; Teer, D.G. A Study of TiMoN Nano-Multilayer Coatings Deposited by CFUBMSIP Using DC and HIPIMS Power. Appl. Surf. Sci. 2012, 258, 2062-2067. [CrossRef]

88. Chen, J.; Ji, R.; Khan, R.H.U.; Li, X.; Beake, B.D.; Dong, H. Effects of Mechanical Properties and Layer Structure on the Cyclic Dynamic Loading of TiN-Based Coatings. Surf. Coat. Technol. 2011, 206, 522-529. [CrossRef]

89. Mendibide, C.; Fontaine, J.; Steyer, P.; Esnouf, C. Dry Sliding Wear Model of Nanometer Scale Multilayered TiN/CrN PVD Hard Coatings. Tribol. Lett. 2004, 17, 779-789. [CrossRef]

90. Vereschaka, A.A.; Grigoriev, S.N. Study of Cracking Mechanisms in Multi-Layered Composite Nano-Structured Coatings. Wear 2017, 378-379, 43-57. [CrossRef]

91. Vereschaka, A.A.; Grigoriev, S.N.; Sitnikov, N.N.; Batako, A.D. Delamination and Longitudinal Cracking in Multi-Layered Composite Nano-Structured Coatings and Their Influence on Cutting Tool Life. Wear 2017, 390-391, 209-219. [CrossRef]

92. Zhang, J.J.; Wang, M.X.; Yang, J.; Liu, Q.X.; Li, D.J. Enhancing Mechanical and Tribological Performance of Multilayered CrN/ZrN Coatings. Surf. Coat. Technol. 2007, 201, 5186-5189. [CrossRef]

93. Paulitsch, J.; Schenkel, M.; Schintlmeister, A.; Hutter, H.; Mayrhofer, P.H. Low Friction CrN/TiN Multilayer Coatings Prepared by a Hybrid High Power Impulse Magnetron Sputtering/DC Magnetron Sputtering Deposition Technique. Thin Solid Films 2010, 518, 5553-5557. [CrossRef]

94. Barshilia, H.C.; Rajam, K.S. Structure and Properties of Reactive DC Magnetron Sputtered TiN/NbN Hard Superlattices. Surf. Coat. Technol. 2004, 183, 174-183. [CrossRef]

95. Helmersson, U.; Todorova, S.; Barnett, S.A.; Sundgren, J.-E.; Markert, L.C.; Greene, J.E. Growth of Single-crystal TiN/VN Strained-layer Superlattices with Extremely High Mechanical Hardness. J. Appl. Phys. 1987, 62, 481-484. [CrossRef] 
96. Nordin, M.; Larsson, M.; Hogmark, S. Mechanical and Tribological Properties of Multilayered PVD TiN/CrN, TiN/MoN, TiN/NbN and TiN/TaN Coatings on Cemented Carbide. Surf. Coat. Technol. 1998, 106, 234-241. [CrossRef]

97. Hovsepian, P.E.; Lewis, D.B.; Münz, W.-D. Recent Progress in Large Scale Manufacturing of Multilayer/Superlattice Hard Coatings. Surf. Coat. Technol. 2000, 133-134, 166-175. [CrossRef]

98. Ou, Y.X.; Lin, J.; Che, H.L.; Moore, J.J.; Sproul, W.D.; Lei, M.K. Mechanical and Tribological Properties of CrN/TiN Superlattice Coatings Deposited by a Combination of Arc-Free Deep Oscillation Magnetron Sputtering with Pulsed Dc Magnetron Sputtering. Thin Solid Films 2015, 594, 147-155. [CrossRef]

99. Pogrebnjak, A.; Ivashchenko, V.; Bondar, O.; Beresnev, V.; Sobol, O.; Załęski, K.; Jurga, S.; Coy, E.; Konarski, P.; Postolnyi, B. Multilayered Vacuum-Arc Nanocomposite TiN/ZrN Coatings before and after Annealing: Structure, Properties, First-Principles Calculations. Mater. Charact. 2017, 134, 55-63. [CrossRef]

100. Pogrebnjak, A.D.; Beresnev, V.M.; Bondar, O.V.; Postolnyi, B.O.; Zaleski, K.; Coy, E.; Jurga, S.; Lisovenko, M.O.; Konarski, P.; Rebouta, L.; et al. Superhard CrN/MoN Coatings with Multilayer Architecture. Mater. Des. 2018, 153, 47-59. [CrossRef]

101. Pogrebnjak, A.D.; Eyidi, D.; Abadias, G.; Bondar, O.V.; Beresnev, V.M.; Sobol, O.V. Structure and Properties of Arc Evaporated Nanoscale TiN/MoN Multilayered Systems. Int. J. Refract. Met. Hard Mater. 2015, 48, 222-228. [CrossRef]

102. Chu, X.; Wong, M.S.; Sproul, W.D.; Rohde, S.L.; Barnett, S.A. Deposition and Properties of Polycrystalline TiN/NbN Superlattice Coatings. J. Vac. Sci. Technol. Vac. Surf. Films 1992, 10, 1604-1609. [CrossRef]

103. Sproul, W.D. High-Rate Reactive DC Magnetron Sputtering of Oxide and Nitride Superlattice Coatings. Vacuum 1998, 51, 641-646. [CrossRef]

104. Chu, X.; Barnett, S.A.; Wong, M.S.; Sproul, W.D. Reactive Unbalanced Magnetron Sputter Deposition of Polycrystalline TiN/NbN Superlattice Coatings. Surf. Coat. Technol. 1993, 57, 13-18. [CrossRef]

105. Luo, Q.; Zhou, Z.; Rainforth, W.M.; Hovsepian, P.E. TEM-EELS Study of Low-Friction Superlattice TiAIN/VN Coating: The Wear Mechanisms. Tribol. Lett. 2006, 24, 171-178. [CrossRef]

106. Zhou, Z.; Calvert, C.C.; Rainforth, W.M.; Luo, Q.; Chen, L.; Hovsepian, P.E. Investigating Worn Surfaces of Nanoscale TiAIN/VN Multilayer Coating Using FIB and TEM. J. Phys. Conf. Ser. 2006, 26, 95. [CrossRef]

107. Hovsepian, P.E.; Luo, Q.; Robinson, G.; Pittman, M.; Howarth, M.; Doerwald, D.; Tietema, R.; Sim, W.M.; Deeming, A.; Zeus, T. TiAlN/VN Superlattice Structured PVD Coatings: A New Alternative in Machining of Aluminium Alloys for Aerospace and Automotive Components. Surf. Coat. Technol. 2006, 201, 265-272. [CrossRef]

108. Tytko, D.; Choi, P.-P.; Raabe, D. Oxidation Behavior of AlN/CrN Multilayered Hard Coatings. Nano Converg. 2017, 4, 15. [CrossRef] [PubMed]

109. Chang, Y.-Y.; Yang, S.-J.; Wang, D.-Y. Characterization of $\operatorname{TiCr}(\mathrm{C}, \mathrm{N}) /$ Amorphous Carbon Coatings Synthesized by a Cathodic Arc Deposition Process. Thin Solid Films 2007, 515, 4722-4726. [CrossRef]

110. Aouadi, S.M.; Wong, K.C.; Mitchell, K.A.R.; Namavar, F.; Tobin, E.; Mihut, D.M.; Rohde, S.L. Characterization of Titanium Chromium Nitride Nanocomposite Protective Coatings. Appl. Surf. Sci. 2004, 229, 387-394. [CrossRef]

111. Lin, J.; Moore, J.J.; Mishra, B.; Pinkas, M.; Sproul, W.D. Nano-Structured CrN/AlN Multilayer Coatings Synthesized by Pulsed Closed Field Unbalanced Magnetron Sputtering. Surf. Coat. Technol. 2009, 204, 936-940. [CrossRef]

112. Rizzo, A.; Signore, M.A.; Valerini, D. PVD Protective Multilayer Coatings for Tribological Applications. Energ. Ambient Innov. 2012, 3, 102-108.

113. Chu, X.; Barnett, S.A. Model of Superlattice Yield Stress and Hardness Enhancements. J. Appl. Phys. 1995, 77, $4403-4411$. [CrossRef]

114. Anderson, P.M.; Li, C. Hall-Petch Relations for Multilayered Materials. Nanostruct. Mater. 1995, 5, 349-362. [CrossRef]

115. Caicedo, J.C.; Amaya, C.; Yate, L.; Gómez, M.E.; Zambrano, G.; Alvarado-Rivera, J.; Muñoz-Saldaña, J.; Prieto, P. TiCN/TiNbCN Multilayer Coatings with Enhanced Mechanical Properties. Appl. Surf. Sci. 2010, 256, 5898-5904. [CrossRef]

116. Kato, M.; Mori, T.; Schwartz, L.H. Hardening by Spinodal Modulated Structure. Acta Metall. 1980, $28,285-290$. [CrossRef]

117. Cammarata, R.C. The Supermodulus Effect in Compositionally Modulated Thin Films. Scr. Metall. 1986, $20,479-486$. [CrossRef] 
118. Bondar, O.V.; Stolbovoy, V.A.; Kylyshkanov, M.K.; Plotnikov, S.V.; Erdybaeva, N.K.; Piotrowska, K.; Czarnacka, K.; Karwat, C. Dependence of Mechanical and Tribotechnical Properties of Multilayered TiN/ZrN Coatings on Deposition. Przeglad Elektrotechniczny 2015, 91, 233-236. [CrossRef]

119. Zhang, Z.G.; Rapaud, O.; Allain, N.; Mercs, D.; Baraket, M.; Dong, C.; Coddet, C. Microstructures and Tribological Properties of CrN/ZrN Nanoscale Multilayer Coatings. Appl. Surf. Sci. 2009, 255, 4020-4026. [CrossRef]

120. Pogrebnjak, A.D.; Bondar, O.V.; Abadias, G.; Eyidi, D.; Beresnev, V.M.; Sobol, O.V.; Postolnyi, B.O.; Zukowski, P. Investigation of Nanoscale TiN/MoN Multilayered Systems, Fabricated Using Arc Evaporation. Acta Phys. Pol. A 2015, 128, 836-840. [CrossRef]

121. Veprek, S.; Veprek-Heijman, M.G.J.; Karvankova, P.; Prochazka, J. Different Approaches to Superhard Coatings and Nanocomposites. Thin Solid Films 2005, 476, 1-29. [CrossRef]

122. Beresnev, V.M.; Klimenko, S.A.; Sobol', O.V.; Grankin, S.S.; Stolbovoi, V.A.; Turbin, P.V.; Novikov, V.Y.; Meilekhov, A.A.; Litovchenko, S.V.; Malikova, L.V. Effect of the Deposition Parameters on the Phase-Structure State, Hardness and Tribological Characteristics of Mo2N/CrN Vacuum-Arc Multilayer Coatings. J. Superhard Mater. 2016, 38, 114-122. [CrossRef]

123. Pogrebnjak, A.D.; Bondar, O.V.; Erdybaeva, N.K.; Plotnikov, S.V.; Turbin, P.V.; Grankin, S.S.; Stolbovoy, V.A.; Sobol, O.V.; Kolesnikov, D.A.; Kozak, C. Influence of Thermal Annealing and Deposition Conditions on Structure and Physical-Mechanical Properties of Multilayered Nanosized TiN/ZrN Coatings. Przeglad Elektrotechniczny 2015, 91, 228-232.

124. Musil, J. Hard Nanocomposite Coatings: Thermal Stability, Oxidation Resistance and Toughness. Surf. Coat. Technol. 2012, 207, 50-65. [CrossRef]

125. Pogrebnjak, A.D.; Beresnev, V.M.; Bondar, O.V.; Abadias, G.; Chartier, P.; Postol'nyi, B.A.; Andreev, A.A.; Sobol', O.V. The Effect of Nanolayer Thickness on the Structure and Properties of Multilayer TiN/MoN Coatings. Tech. Phys. Lett. 2014, 40, 215-218. [CrossRef]

126. Postolnyi, B.O.; Beresnev, V.M.; Abadias, G.; Bondar, O.V.; Rebouta, L.; Araujo, J.P.; Pogrebnjak, A.D. Multilayer Design of CrN/MoN Protective Coatings for Enhanced Hardness and Toughness. J. Alloy. Compd. 2017, 725, 1188-1198. [CrossRef]

127. Bondar, O.V.; Postol'nyi, B.A.; Beresnev, V.M.; Abadias, G.; Chartier, P.; Sobol, O.V.; Kolesnikov, D.A.; Komarov, F.F.; Lisovenko, M.O.; Andreev, A.A. Composition, Structure and Tribotechnical Properties of TiN, MoN Single-Layer and TiN/MoN Multilayer Coatings. J. Superhard Mater. 2015, 37, 27-38. [CrossRef]

128. Postolnyi, B.; Bondar, O.; Opielak, M.; Rogalski, P.; Araújo, J.P. Structural Analysis of Multilayer Metal Nitride Films CrN/MoN Using Electron Backscatter Diffraction (EBSD). In SPIE-Advanced Topics in Optoelectronics, Microelectronics and Nanotechnologies VIII; SPIE: Bellingham, WA, USA, 2016; Volume 10010, p. 100100E. [CrossRef]

129. Pogrebnyak, A.D.; Bondar, O.V.; Zhollybekov, B.; Konstantinov, S.; Konarski, P.; Beresnev, V.M.; Kupchishin, A.I. Influence of the Bilayer Thickness of Nanostructured Multilayer MoN/CrN Coating on Its Microstructure, Hardness and Elemental Composition. Phys. Solid State 2017, 59, 1798-1802. [CrossRef]

130. Li, N.; Liu, X.-Y. Review: Mechanical Behavior of Metal/Ceramic Interfaces in Nanolayered Composites-Experiments and Modeling. J. Mater. Sci. 2018, 53, 5562-5583. [CrossRef]

131. Liu, Y.; Bufford, D.; Wang, H.; Sun, C.; Zhang, X. Mechanical Properties of Highly Textured Cu/Ni Multilayers. Acta Mater. 2011, 59, 1924-1933. [CrossRef]

132. Khomenko, A.V.; Prodanov, N.V. Molecular Dynamics of Cleavage and Flake Formation during the Interaction of a Graphite Surface with a Rigid Nanoasperity. Carbon 2010, 48, 1234-1243. [CrossRef]

133. Rogström, L.; Johnson, L.J.S.; Johansson, M.P.; Ahlgren, M.; Hultman, L.; Odén, M. Thermal Stability and Mechanical Properties of Arc Evaporated ZrN/ZrAlN Multilayers. Thin Solid Films 2010, 519, 694-699. [CrossRef]

134. Kato, K.; Adachi, K. Wear Mechanisms. In Modern Tribology Handbook, Two Volume Set; Bhushan, B., Ed.; CRC Press: Boca Raton, FL, USA, 2000; pp. 273-299.

135. Ge, F.; Zhu, P.; Meng, F.; Huang, F. Enhancing the Wear Resistance of Magnetron Sputtered VN Coating by Si Addition. Wear 2016, 354-355, 32-40. [CrossRef]

136. Pogrebnjak, A.D.; Abadias, G.; Bondar, O.V.; Postolnyi, P.O.; Lisovenko, M.O.; Kyrychenko, O.V.; Andreev, A.A.; Beresnev, V.M.; Kolesnikov, D.A.; Opielak, M. Structure and Properties of Multilayer Nanostructured Coatings TiN/MoN Depending on Deposition Conditions. Acta Phys. Pol. A 2014, 125, 1280-2183. [CrossRef] 
137. Bendavid, A.; Martin, P.J.; Kinder, T.J.; Preston, E.W. The Deposition of NbN and NbC Thin Films by Filtered Vacuum Cathodic Arc Deposition. Surf. Coat. Technol. 2003, 163-164, 347-352. [CrossRef]

138. Pogrebnjak, A.D.; Beresnev, V.M. Nanocoatings Nanosystems Nanotechnologies, 1st ed.; Bentham Science: Emirate of Sharjah, UAE, 2012.

139. Beake, B.D.; Fox-Rabinovich, G.S. High-Temperature Coatings. In Multifunctional Materials for Tribological Applications; Wood, R.J.K., Ed.; CRC Press: Boca Raton, FL, USA, 2015; pp. 161-203.

140. Guo, J.; Wang, H.; Meng, F.; Liu, X.; Huang, F. Tuning the H/E* Ratio and $E^{*}$ of AlN Coatings by Copper Addition. Surf. Coat. Technol. 2013, 228, 68-75. [CrossRef]

141. Khomenko, A.V.; Yushchenko, O.V. Solid-Liquid Transition of Ultrathin Lubricant Film. Phys. Rev. E Stat. Nonlin. Soft Matter Phys. 2003, 68, 036110. [CrossRef] [PubMed]

142. Pogrebnjak, A.D.; Kravchenko, Y.O.; Bondar, O.V.; Zhollybekov, B.; Kupchishin, A.I. Structural Features and Tribological Properties of Multilayer Coatings Based on Refractory Metals. Prot. Met. Phys. Chem. Surf. 2018, 54, 240-258. [CrossRef]

143. Ou, Y.X.; Lin, J.; Che, H.L.; Sproul, W.D.; Moore, J.J.; Lei, M.K. Mechanical and Tribological Properties of CrN/TiN Multilayer Coatings Deposited by Pulsed Dc Magnetron Sputtering. Surf. Coat. Technol. 2015, 276, 152-159. [CrossRef]

144. Ahmad, Z. Chapter 7-Coatings. In Principles of Corrosion Engineering and Corrosion Control; Ahmad, Z., Ed.; Butterworth-Heinemann: Oxford, UK, 2006; pp. 382-437. [CrossRef]

145. De Sánchez, N.A.; Suárez, H.E.J.; Vivas, Z. Fracture Resistant and Wear Corrosion Performance of CrN/ZrN Bilayers Deposited onto AISI 420 Stainless Steel. Adv. Mater. Res. 2008, 38, 63-75. [CrossRef]

146. Khaled, K.F.; Al-Mhyawi, S.R. Electrochemical and Density Function Theory Investigations of L- Arginine as Corrosion Inhibitor for Steel in 3.5\% NaCl. Int. J. Electrochem. Sci. 2014, 8, 4055-4072.

147. Maksakova, O.V.; Pogrebnjak, A.D.; Beresnev, V.M. Features of Investigations of Multilayer Nitride Coatings Based on Cr and Zr. Usp Fiz Met 2018, 19, 25-48. [CrossRef]

148. Dehgahi, S.; Amini, R.; Alizadeh, M. Corrosion, Passivation and Wear Behaviors of Electrodeposited $\mathrm{Ni}-\mathrm{Al}_{2} \mathrm{O}_{3}-\mathrm{SiC}$ Nano-Composite Coatings. Surf. Coat. Technol. 2016, 304, 502-511. [CrossRef]

149. Chen, Z.; Chen, Y.; Dong, D.; Yang, Q.; Hu, M. Tribological Performance of SiC Coating for Carbon/Carbon Composites at Elevated Temperatures. Ceram. Int. 2018, 44, 11233-11238. [CrossRef]

150. Li, Y.; Liang, W.; Shi, Y.; Zhou, W. LPCVD-Based $\mathrm{SiO}_{2} / \mathrm{SiC}$ Multi-Layers Coating on Graphite for Improved Anti-Oxidation at Wide-Ranged Temperatures. Compos. Part B Eng. 2018, 146, 155-164. [CrossRef]

151. Kot, M.; Major, L.; Lackner, J.; Rakowski, W. Carbon Based Coatings with Improved Fracture and Wear Resistance. In Innovations in Biomedical Engineering; Gzik, M., Tkacz, E., Paszenda, Z., Piętka, E., Eds.; Advances in Intelligent Systems and Computing; Springer International Publishing: Cham, Switzerland, 2017; pp. 40-48.

152. Pogrebnjak, A.D.; Ivashchenko, V.I.; Skrynskyy, P.L.; Bondar, O.V.; Konarski, P.; Załęski, K.; Jurga, S.; Coy, E. Experimental and Theoretical Studies of the Physicochemical and Mechanical Properties of Multi-Layered TiN/SiC Films: Temperature Effects on the Nanocomposite Structure. Compos. Part B Eng. 2018, 142, 85-94. [CrossRef]

153. Giannozzi, P.; Baroni, S.; Bonini, N.; Calandra, M.; Car, R.; Cavazzoni, C.; Ceresoli, D.; Chiarotti, G.L.; Cococcioni, M.; Dabo, I.; et al. QUANTUM ESPRESSO: A Modular and Open-Source Software Project for Quantum Simulations of Materials. J. Phys. Condens. Matter 2009, 21, 395502. [CrossRef] [PubMed]

154. Daviau, K.; Lee, K.K.M. Zinc-Blende to Rocksalt Transition in SiC in a Laser-Heated Diamond-Anvil Cell. Phys. Rev. B 2017, 95, 134108. [CrossRef]

(C) 2019 by the authors. Licensee MDPI, Basel, Switzerland. This article is an open access article distributed under the terms and conditions of the Creative Commons Attribution (CC BY) license (http://creativecommons.org/licenses/by/4.0/). 